\title{
Influence of Molarity and Chemical Composition on the Development of Compressive Strength in POFA Based Geopolymer Mortar
}

\author{
S. M. Alamgir Kabir, U. Johnson Alengaram, Mohd Zamin Jumaat, \\ Afia Sharmin, and Azizul Islam \\ Department of Civil Engineering, Faculty of Engineering, University of Malaya, 50603 Kuala Lumpur, Malaysia \\ Correspondence should be addressed to U. Johnson Alengaram; ujohnrose@yahoo.com
}

Received 23 September 2014; Revised 3 January 2015; Accepted 8 January 2015

Academic Editor: Hao Wang

Copyright (C) 2015 S. M. Alamgir Kabir et al. This is an open access article distributed under the Creative Commons Attribution License, which permits unrestricted use, distribution, and reproduction in any medium, provided the original work is properly cited.

The investigation concerns the use of the optimum mix proportion of two locally available pozzolanic waste materials, namely, ground granulated blast furnace slag (GGBS) and palm oil fuel ash (POFA), together with metakaolin (MK) as binders. In addition, another local waste material, manufactured sand (M-sand), was used as a replacement for conventional sand in the development of green geopolymer mortar. Twenty-four mortar mixtures were designed with varying binder contents and alkaline activators. The oven dry curing was also kept consistent for all the mix proportions at a temperature of $65^{\circ} \mathrm{C}$ for 24 hours. The highest 28 -day compressive strength of about $48 \mathrm{MPa}$ was obtained for the mortar containing $20 \%$ of MK, 35\% of GGBS, and $45 \%$ of POFA. The increment of MK beyond $20 \%$ leads to reduction of the compressive strength. The GGBS replacement beyond $35 \%$ also reduced the compressive strength. The entire specimen achieved average $80 \%$ of the 28 -day strength at the age of 3 days. The density decreased with the increase of POFA percentage. The finding of this research by using the combination of MK, GGBS, and POFA as binders to wholly replace conventional ordinary Portland cement would lead to alternate eco-friendly geopolymer matrix.

\section{Introduction}

The utilization of waste materials or industrial by-products, such as fly ash (FA), metakaolin (MK), silica fume (SF), ground granulated blast furnace slag (GGBS), rich husk ash (RHA), and palm oil fuel ash (POFA), as binders in the development of geopolymer concrete is gaining momentum [1-3] due to the overuse of virgin materials in the production of ordinary Portland cement (OPC). The use of OPC has resulted in a high volume of carbon dioxide $\left(\mathrm{CO}_{2}\right)$ emissions, as the construction industries cannot replace the use of OPC entirely with the other cementitious materials due to the huge demand for concrete. The extraction of natural deposits in the production of cement and concrete has led to an ecological imbalance due to the continuous depletion of natural resources. The present annual consumption of 2.9 billion tons of cement globally could increase to 4 billion tons by 2020 [4]. The estimated value of $\mathrm{CO}_{2}$ emission in the production of 1 ton OPC is about 0.6 tons [5]. The cement industry is responsible for approximately $5 \%$ of global $\mathrm{CO}_{2}$ emissions and it is likely to reach $6 \%$ annually by 2015 [6].

The ratio of clinker to cement is the main fact upon which the $\mathrm{CO}_{2}$ emissions per ton of cement depend. Normally this ratio varies from 0.5 to 0.95 [7]. The $\mathrm{CaO}$ share in clinker amounts to $64-67 \%$. The rest consists of silicon oxides, iron oxides, and aluminium oxides. On the other hand, the production of industrial by-products and other waste materials, such as FA, GGBS, RHA, SF, POFA, and MK, continues to rise and the waste disposal of these materials in an environmentally friendly manner is becoming a challenge. The use of these waste materials in the production of concrete could reduce the greenhouse gas emissions [8]. Geopolymers are usually reported to be much more sustainable than Portland cement, in terms of reduced production energy 


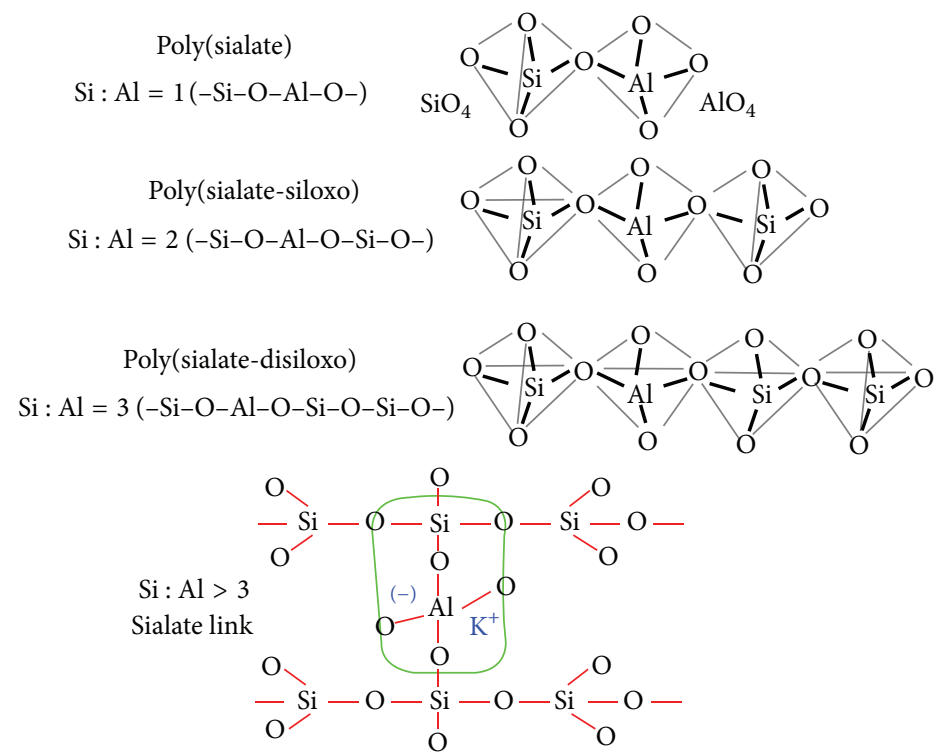

FIGURE 1: Geopolymer terminology [11].

necessity, lower $\mathrm{CO}_{2}$ emissions comparing with the $\mathrm{OPC}$ concrete; Turner and Collins (2013) [9] have pointed out only $9 \%$ less $\mathrm{CO}_{2}$ emission from geopolymer concrete production considering curing as well as FA, sodium silicate, and sodium hydroxide production. The emission of $\mathrm{CO}_{2}$ from geopolymer concrete may control considering emissions during curing as well as production of FA, sodium silicate, and sodium hydroxide. Geopolymers are a class of synthetic alkaliactivated alumina silicate inorganic polymers (AIPs) featuring a predominantly $\mathrm{X}$-ray amorphous three-dimensional network [10]. Glukhovsky carried out the maiden work on alkali-activated alumina silicate materials in the 1950s, which consisted of mixed alkalis with a burnt mixture of kaolinite, limestone, and dolomite. Later, binders other than cement could be produced by the reaction between alkaline solution and source materials that are rich in silica $\left(\mathrm{SiO}_{2}\right)$ and alumina $\left(\mathrm{Al}_{2} \mathrm{O}_{3}\right)$. Davidovits was the pioneer in introducing the term known as geopolymer and [11] further categorized the geopolymer structure based on the ratio of $\mathrm{Si} / \mathrm{Al}$ (Figure 1).

Duxson et al. [12] proposed another model for the mechanism of geopolymerisation (Figure 2), which consisted of (a) dissolution, (b) speciation equilibrium, (c) gelation, (d) reorganization, and (e) polymerization and hardening. The type of alkaline activator plays an important role in the geopolymerisation process and has a significant effect on the mechanical strength of the geopolymer.

Provis and van Deventer (2009) pointed out the reality of the geopolymer gel structure and the Davidovits sialate nomenclature implies certain aspects of the geopolymer gel structure which do not correspond to reality [14]. Provis (2014) has recently presented latest definition of the geopolymer structure. Provis [15] reported that geopolymers are produced through the reaction of an aluminosilicate, normally supplied in powder form as an industrial by-product or other inexpensive material, with an alkaline activator, which is

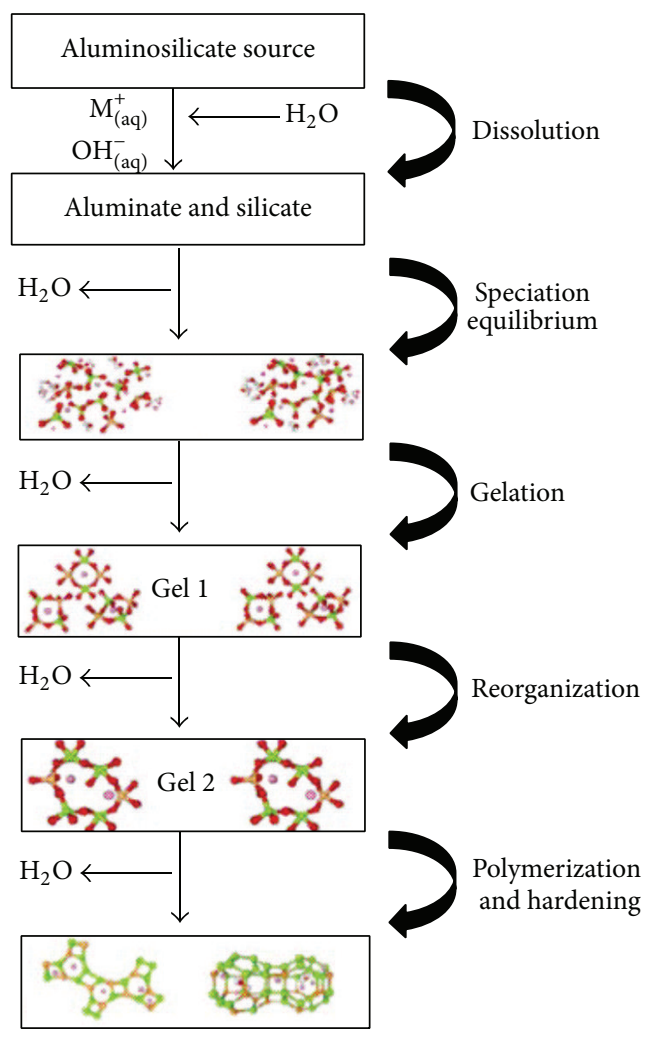

FIGURE 2: Geopolymerisation-conceptual model [12].

usually a concentrated aqueous solution of alkali hydroxide, silicate, carbonate, or sulfate.

The commonly used alkaline activators in current times are combinations of sodium hydroxide solution $(\mathrm{NaOH})$ 
and sodium silicate solution $\left(\mathrm{Na}_{2} \mathrm{SiO}_{3}\right)$ with different $\mathrm{Na}_{2} \mathrm{SiO}_{3} / \mathrm{NaOH}$ mass ratios [16]. Geopolymers can be progressed through a series of several distinct reaction processes from initial pozzolanic activation to final microstructure development, which is very similar to zeolites. The rate of strength development and the chemical reaction of geopolymer concrete are influenced by several factors based on the chemical composition of the source materials, alkaline activators, and curing conditions [17].

Due to the pure alumina silicate content of metakaolin (MK), it was used in the early development of geopolymers and has continued to be used as a raw material. MK is obtained by the calcination of kaolinitic clay at a temperature ranging between $500^{\circ} \mathrm{C}$ and $800^{\circ} \mathrm{C}$, and, of course, it is a pozzolanic material. The comparison between OPC and MK shows that the latter is environmentally friendly as its production requires a much lower calcining temperature and emits $80-90 \%$ less $\mathrm{CO}_{2}$ than the former [18]. $\mathrm{MK}$ is a good source of $\mathrm{Al}_{2} \mathrm{O}_{3}$ and $\mathrm{SiO}_{2}$ and is highly reactive with alkaline activators and produces a higher degree of geopolymerization. $\mathrm{MK}$ is a better material for geopolymers because it has a higher amorphous phase content and smaller sized particles, the compressive strength of MKbased geopolymers increases with an increase of alumina content by up to $20 \%$ [19]. Islam et al. [13] reported that with the increase of GGBS content in the matrix containing FA and POFA the compressive strength of geopolymer mortar could be increased. The addition of calcium from other sources in geopolymer based on metakaolin improved its mechanical strength [20]. Depolymerised siliceous structures with raw materials, such as GGBS, exhibit higher dissolution rates under high alkalinity conditions compared with raw materials composed of laminar structures such as MK. Therefore, blending these components can contribute to an improvement in the stability of the system, and, potentially, also to the durability, when compared to the binders prepared from a single raw material.

Malaysia is one of the largest producers of POFA. There are nearly 200 palm oil mills operating in Malaysia, which produce about 100 tons of POFA annually. In addition, although due to the increased plantation of palm oil trees this production rate is likely to increase [21], this material has no market value and is simply dumped into ponds/lagoons [22], which causes environmental pollution. However, recent research $[23,24]$ has paved the way for the development of sustainable material using POFA and related waste materials from the palm oil industry. Such development has become more significant as a number of studies have identified it as being rich in silica. Alengaram et al. [23] reported that the compressive strength of concrete can improve with the increase in sand content coupled with a reduction in OPS content. POFA is a cementitious material that could be used with recycled aggregate concrete that could result in a higher compressive strength than that of recycled aggregate concrete without POFA [25].

For centuries, river or mining sand was used as fine aggregate even though river sand is a nonrenewable natural resource. The exploitation of river sand endangers the stability of riverbanks and creates environmental problems, such as flooding and the reduction of ground water level. Thus, the urgency to find an alternate to natural sand is vital. Cai [26] suggested the use of alternative materials for river sand, such as manufactured sand (M-sand), industrial by-products (some forms of slag, bottom ash), and recycled aggregates. Among these, the use of manufactured sand is gaining momentum [26]. M-sand, which is a by-product of quarry dust (QD), is obtained by centrifuging it using a technology known as the vertical shaft impact (VSI). QD, which is the byproduct of rock crushing, contains angular and flaky edged particles. Hence, the process of VSI technology produces particle sizes with greater integrity and a more isometric shape. M-sand fines contribute to an increase in paste volume [27] and the shape and texture of M-sand lead to improved strength due to better interlocking between the particles.

During the last two decades, there have been a number of researchers who focused their efforts to utilize geopolymer concrete due to the wide range of potential applications $[8$, $9,15]$. The effect of single and binary combination of binders among MK, GGBS, and POFA has been reported by previous researchers [28-30]. Islam et al. [13] reported the highest compressive strength of about $66 \mathrm{MPa}$ by using $70 \%$ GGBS with $30 \%$ POFA. However, the use of large amount of GGBS leads to workability and setting time problems. Sahana [31] reported that the inclusion of GGBS at different replacement levels below $40 \%$ increases the setting time of mortar, but beyond this level, the setting time decreases and this could lead to loss of workability and casting of concrete; Deb et al. [32] described that the workability decreased with the high content of GGBS due to accelerated reaction of the calcium and the angular shape of GGBS. Islam et al. [13] also used 12molarity sodium hydroxide solution to obtain the maximum compressive strength; however the effect of higher molarity was not investigated.

Thus these research questions, such as the loss of workability and early setting due to high GGBS content, have to be addressed. In order to address this issue, an attempt has been made through this research work to minimize the use of GGBS content within 20-45\%; and at the same time to ensure the required compressive strength, POFA and MK were used along with GGBS. Therefore, the research focus of this work is to utilize ternary binders and at the same time to optimize the local waste material, POFA as binder. Utilization of $45 \%$ of POFA along with $35 \%$ and $20 \%$ of GGBS and MK, respectively, was experimented and the main flaw of low workability was investigated. The use of hydroxide solution with 12 and 14 molarities on the compressive strength was also carried out.

The variables investigated in the research are different percentages of binder, sand, and two molarities of alkali activators to obtain maximum compressive strength. In this study M-sand was used as fine aggregate for the replacement of conventional mining sand. The other parameters, such as $\mathrm{M}$-sand and water contents, were kept constant. The flow ability, oven dry density, and compressive strength at different ages of cube specimens were tested and reported in this investigation. A total of 24 mixes were prepared to obtain the optimum mix that could be used for further works. 


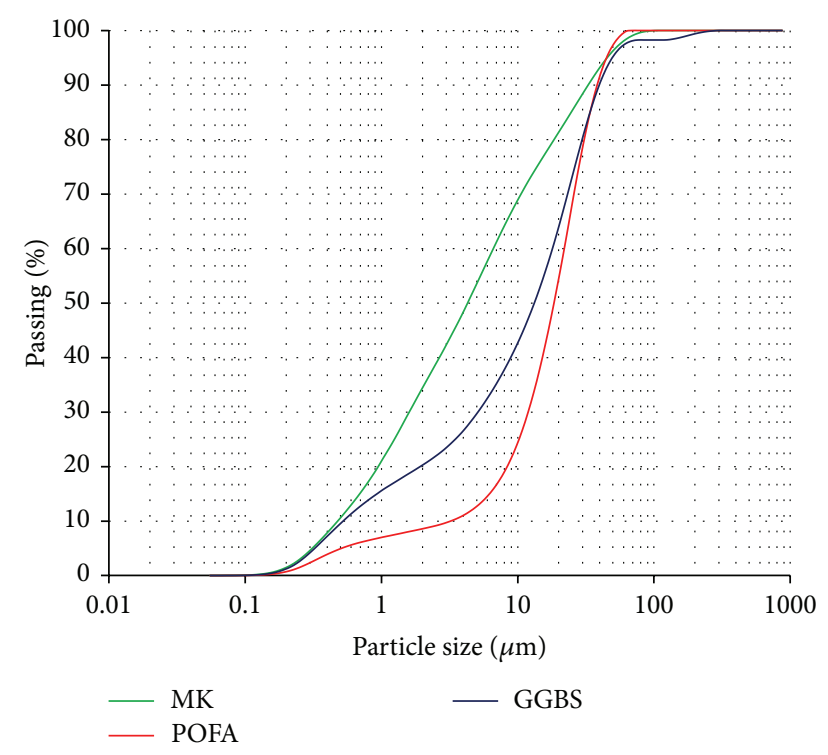

Figure 3: MK, GGBS, and POFA's particle size distribution (log scale).

\section{Experimental Programme}

\subsection{Materials}

2.1.1. Metakaolin. Metakaolin (MK) is an industrial byproduct material, it has significant potential in the development of concrete composites, and it is a highly reactive pozzolanic admixture. MK is manufactured from a natural geological mineral that often contains impurities and inconsistent $\mathrm{Si}: \mathrm{Al}$ atomic ratios. The chemical composition of MK and the physical properties are given in Tables 1 and 2, respectively. It can be seen from the chemical composition that MK contains $90 \%$ silica and alumina. The physical properties show that MK has a specific gravity and specific surface area of 2.5 and $2.16 \mathrm{~m}^{2} / \mathrm{gm}$, respectively. The particle size distribution of $\mathrm{MK}$ is shown in Figure 3, which shows that $\mathrm{MK}$ is much finer than GGBS or POFA.

2.1.2. Ground Granulated Blast Furnace Slag. Ground granulated blast furnace slag (GGBS) was used as one of the source materials to produce a cementless binder. GGBS was collected from YTL Cement Marketing Sdn Bhd, Malaysia. GGBS has both cementitious and pozzolanic properties and is different from other supplementary cementitious materials. GGBS develops its own hydraulic reaction when mixed with water. GGBS is off-white in colour. The combination of calcium, silicates, and alumina comprising about $90 \%$ of GGBS shows that it satisfies the requirements of a pozzolanic material. Table 1 shows the chemical composition of GGBS, and its physical properties are given in Table 2 . The specific gravity is $2.89 \mathrm{~g} / \mathrm{cm}^{3}$ and specific surface area is $2.36 \mathrm{~m}^{2} / \mathrm{gm}$. The particle size distribution of GGBS is shown in Figure 3.

2.1.3. Palm Oil Fuel Ash. Palm oil fuel ash (POFA) is a waste material; it is obtained from palm oil mill boilers by
TABLE 1: The raw materials (MK, GGBS, and POFA) chemical composition (wt \%).

\begin{tabular}{lccc}
\hline Chemical composition & MK & GGBS & POFA \\
\hline $\mathrm{CaO}$ & 0.04 & 45.83 & 4.34 \\
$\mathrm{SiO}_{2}$ & 52.68 & 32.52 & 63.41 \\
$\mathrm{Al}_{2} \mathrm{O}_{3}$ & 42.42 & 13.7 & 5.55 \\
$\mathrm{MgO}$ & 0.12 & 3.27 & 3.74 \\
$\mathrm{Na}_{2} \mathrm{O}$ & 0.07 & 0.25 & 0.16 \\
$\mathrm{SO}_{3}$ & 0.05 & 1.8 & 0.91 \\
$\mathrm{P}_{2} \mathrm{O}_{5}$ & 0.4 & 0.04 & 3.78 \\
$\mathrm{~K}_{2} \mathrm{O}$ & 0.34 & 0.48 & 6.33 \\
$\mathrm{TiO}_{2}$ & 1.46 & 0.73 & 0.33 \\
$\mathrm{MnO}_{\mathrm{Fe}} \mathrm{O}_{3}$ & 0.08 & 0.35 & 0.17 \\
$\mathrm{SrO}$ & 2.01 & 0.76 & 4.19 \\
$\mathrm{Cl}$ & 0.03 & 0.08 & 0.02 \\
$\mathrm{CuO}$ & - & 0.02 & 0.45 \\
$\mathrm{LOI}$ & - & - & 6.54 \\
\hline
\end{tabular}

TABLE 2: Materials physical properties.

\begin{tabular}{|c|c|c|c|c|}
\hline \multirow{2}{*}{ Properties } & \multicolumn{4}{|c|}{ Materials } \\
\hline & MK & GGBS & POFA & M-sand \\
\hline Specific gravity & 2.5 & 2.89 & 2.2 & 2.78 \\
\hline $\begin{array}{l}\text { Specific surface } \\
\text { area }\left(\mathrm{m}^{2} / \mathrm{gm}\right)\end{array}$ & 2.16 & 2.36 & 1.65 & - \\
\hline Colour & Off-white & Off-white & Dark & - \\
\hline
\end{tabular}

the burning of palm oil husk and shell as fuel. However, this ash has pozzolanic properties that play an active role in making strong and durable concrete by the replacement of cement. Raw POFA was collected from the local palm oil industry, Malaysia. The incompletely combusted fibres and kernel shells were separated by using a $300 \mu \mathrm{m}$ sieve. Before that, they were dried in an oven for at least $24 \mathrm{~h}$ at $100^{\circ} \mathrm{C}$ to remove the moisture. The POFA was then ground in a ball mill to obtain particle sizes of about $10 \mu \mathrm{m}$. Forty mild steel rods of $10 \mathrm{~mm}$ diameter and $400 \mathrm{~mm}$ length were placed in the rotating drum to grind approximately $10 \mathrm{~kg}$ of POFA one time before being sieved through $300 \mu \mathrm{m}$. To obtain the desired level of fineness ( $>66 \%$ ), the grinding of POFA was carried out for 30,000 cycles over $16 \mathrm{~h}$. The mass of natural pozzolan passing a $45 \mu \mathrm{m}$ wet sieve should be at least $86 \%$ based on ASTM: C618-12a. The POFA was greyish in colour. The physical properties of POFA are shown in Table 2. Its particle size distribution is shown in Figure 3. The fineness of POFA was found to be $88.7 \%$. Table 1 shows the chemical analysis of POFA. The chemical analysis suggests that, in general, this POFA satisfies the requirement to be considered pozzolanic and may be grouped between Class $\mathrm{C}$ and Class $\mathrm{F}$ pozzolana, as specified in ASTM C618-92a.l. Figure 4 shows the palm fruits and the raw POFA in factory. 


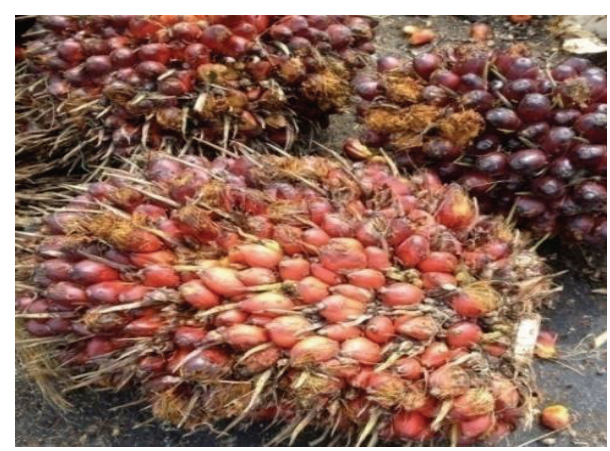

(a)

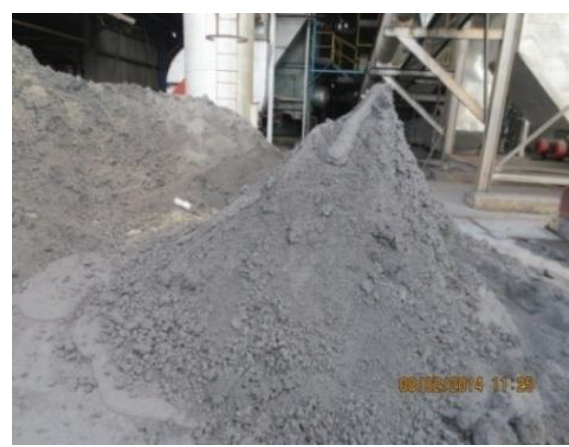

(b)

Figure 4: Palm fruits (left) and raw palm oil fuel ash (right).

2.1.4. Manufactured Sand (M-Sand). M-sand was collected from the local industry in Malaysia. The shape and texture of M-sand particles could lead to improvements in the strength of concrete due to better interlocking between particles. The physical properties of $\mathrm{M}$-sand are shown in Table 2 . The fine aggregate is separated into three grades based on the percentage passing through standard sieves according to BS 882-1992. M-sand falls into the category of grade $\mathrm{C}$ sand. The packing ability of M-sand's finer particles enables the mortar to achieve higher packing density, which could enhance the durability of the concrete. Figure 6 shows that the M-sand has a wide range of particles (metakaolin (MK), palm oil fuel ash (POFA), ground granulated blast furnace slag (GGBS), and manufactured sand (M-sand) are shown in Figure 5).

2.1.5. Alkaline Activators. Sodium hydroxide, silicate, carbonate, and sulphate are the commonly used activators and one of the most common and effective activators are sodium silicate. For the development of geopolymerisation in geopolymer materials, the main contribution of silicate ions is through alkali activation. An activator's efficiency depends on certain factors, such as the type of activator, dosage, ambient temperature, and water to FA (W/FA) ratio. The $\mathrm{NaOH}$ was of commercial grade in pellet form $(5 \mathrm{~mm})$, with a specific gravity of 2.13 and $97 \%$ purity. $\mathrm{Na}_{2} \mathrm{SiO}_{3}$ in liquid form with a density of about $1.5 \mathrm{gm} / \mathrm{mL}$ at $20^{\circ} \mathrm{C}$, a modulus ratio of $2.5\left(\mathrm{SiO}_{2} / \mathrm{Na}_{2} \mathrm{O}, \mathrm{SiO}_{2}=30 \%\right.$ and $\mathrm{Na}_{2} \mathrm{O}=$ $12 \%$, water $=57 \%$ by mass), and specific gravity of 1.5 was used along with $\mathrm{NaOH}$ as an alkali activator according to [33]. Two different molarities (namely, $12 \mathrm{M}$ and $14 \mathrm{M}$ ) were used by using sodium hydroxide solution to obtain the optimum strength. For instance, $\mathrm{NaOH}$ solution with a concentration of $12 \mathrm{M}$ consists of $12 \times 40=480 \mathrm{~g}$ of $\mathrm{NaOH}$ solids per litre of the solution, where 40 is the molecular weight of $\mathrm{NaOH}$. The mass of $\mathrm{NaOH}$ solids was measured as $361 \mathrm{~g}$ per $\mathrm{kg}$ of $\mathrm{NaOH}$ solution of $12 \mathrm{M}$ concentration [34]. The reaction was exothermic, so the solution was made to cool down before use. The ratio of $\mathrm{Na}_{2} \mathrm{SiO}_{3} \mathrm{aq} / \mathrm{NaOH}$ was kept constant at 2.5 for all the mixtures.

2.1.6. Water. Potable water with a $\mathrm{pH}$ value of 6 and free from impurities and chemical contaminants was used in all the mixes. The water to binder ratio of 0.25 was used for all the mixes.

\subsection{Specimen Preparation and Curing}

2.2.1. Mixing Procedure and Casting. A total of 24 mixes were prepared. The mix proportions of all the concrete mixes are shown in Tables 3 and 7. By varying the MK, POFA, GGBS, and activator contents, the mixtures were prepared. To investigate the effect of the binders, the M-sand and water contents were kept constant. The ratio of binder to sand content was kept at 1:2 in all the mixes. In order to mix the ternary binders of MK, POFA, and GGBS along with sand, these materials were mixed in dry condition in a bowl mixer at a low rate of speed for about $5 \mathrm{~min}$. The alkali activator solution was then slowly added into the mix for another $5 \mathrm{~min}$ and the mode of speed was then changed from slow to high. Then, additional water was added to the mix to increase the workability and homogeneity of the mortar. The mortar was then cast in $50 \mathrm{~mm}$ cube moulds and poured in three phases with appropriate compaction. A total of 12 specimens were cast for each mix proportion. To remove the entrained air and bubbles the samples were vibrated with standard compaction using a rod and vibrating table. A comparison between Islam et al. [13] and the present research work on mixing and casting time shows that the former required finishing the casting within $7 \mathrm{~min}$, while the duration could be extended to $10 \mathrm{~min}$ in the present research. Another salient point in the comparison is the total binder content; the present research has total binder content of about $760 \mathrm{~kg} / \mathrm{m}^{3}$ compared to $460 \mathrm{~kg} / \mathrm{m}^{3}$ used by Islam et al. [13]. Thus, the use of such high volume of binder with large quantity of GGBS would have reduced the setting time drastically [31]. Hence, the proposed mixing time with different speed of mixer is crucial in balancing the mix and workability.

2.2.2. Curing Regime. Immediately after casting, the specimens along with the moulds were covered using plastic film to reduce water loss during curing in an oven for $24 \mathrm{~h}$ at $65^{\circ} \mathrm{C}$. Subsequently, the specimens were taken out of the oven and kept at ambient condition with an average temperature and humidity of $28^{\circ} \mathrm{C}$ and $70 \%$, respectively, 


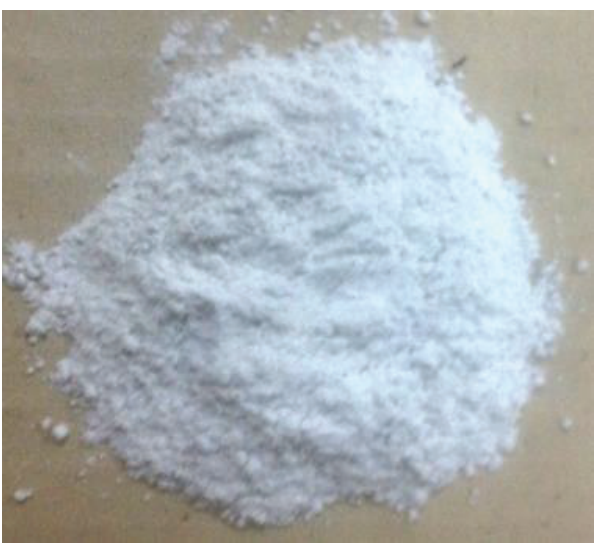

(a)

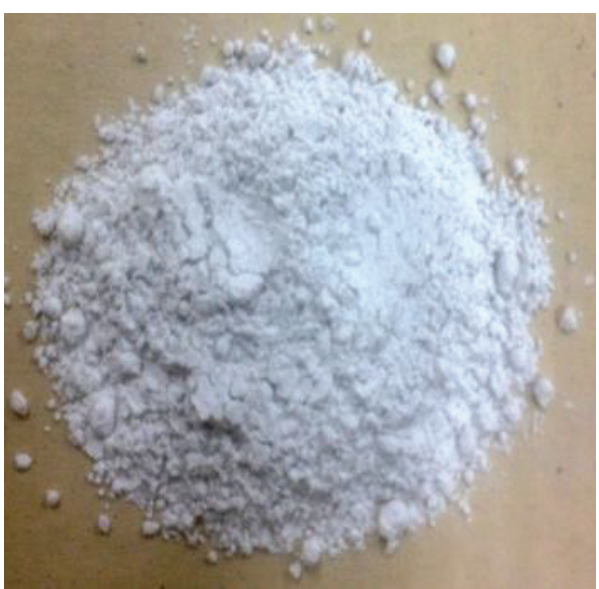

(c)

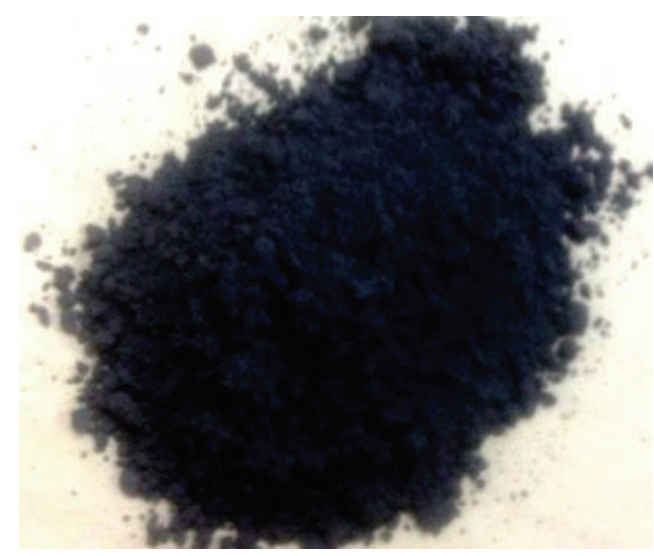

(b)

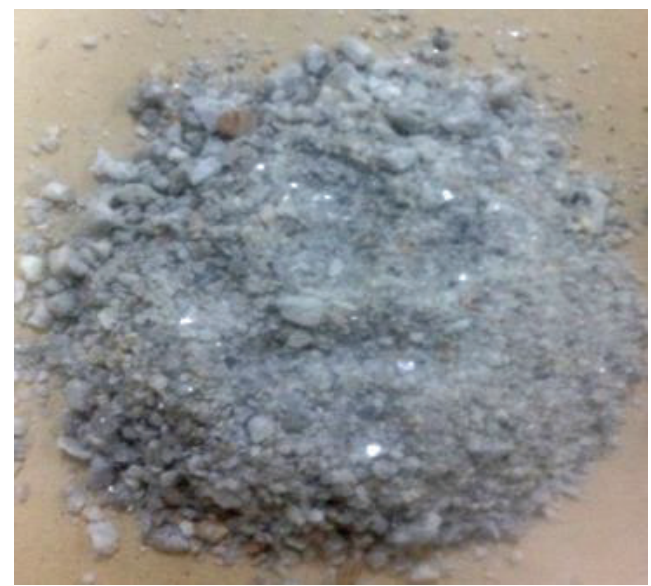

(d)

FIGURE 5: (a) Metakaolin (MK), (b) palm oil fuel ash (POFA), (c) ground granulated blast furnace slag (GGBS), and (d) manufactured sand (M-sand).

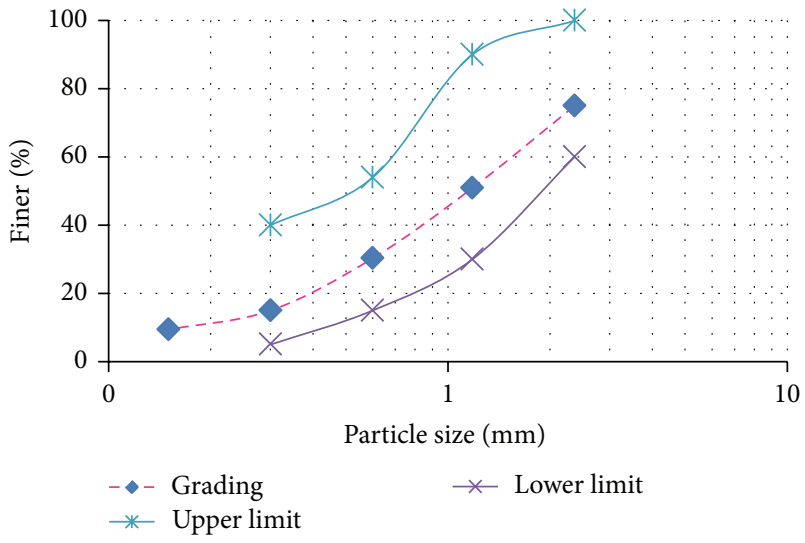

Figure 6: The particle size distribution of M-sand [13].

until testing day. This procedure was adopted from the method suggested by Hardjito and Rangan [34]. To gain high early strength geopolymers with acceptable physical and mechanical properties, the optimum geopolymer oven curing temperature was between $60^{\circ} \mathrm{C}$ and $65^{\circ} \mathrm{C}$ [35]. Therefore, the selection of $65^{\circ} \mathrm{C}$ was justified as the $50 \mathrm{~mm}$ cubes have high surface to volume ratio and are more susceptible to curing heat and to moisture loss.

2.2.3. Compressive Strength. The compressive strength test was done using an ELE Auto Compressive Testing Machine in accordance with ASTM: C109/C109M-13. The compressive strength of the specimens was tested after 3, 7, 14, and 28 days. Each day's compressive strength value was determined as the average of three specimens. The compressive strength of the specimen was determined by dividing the maximum load carried by the specimen during the test by the average crosssectional area. The failure mode of the specimens is shown in Figure 7(a) and that was found satisfactory as specified in BS EN 12390-3:2002 (Figure 7(b)). Compressive strength = Failure load/Cross-sectional area.

2.2.4. Flow Test. The flow test was done according to the ASTM C230 standard [36]. The used apparatus comprised a flow table, flow mould, tamper, trowel, and measuring tape. The flow test can give an indication as to the consistency, filling ability, and workability of the mortar. 
TABLE 3: Mix design for development of compressive strength of geopolymer mortar.

\begin{tabular}{lccccc}
\hline Mortar designation & $\begin{array}{c}\text { Mix proportion }(\%) \\
\text { MK/GGBS/POFA }\end{array}$ & $\begin{array}{c}\text { MK content } \\
\left(\mathrm{kg} / \mathrm{m}^{3}\right)\end{array}$ & $\begin{array}{c}\text { GGBS content } \\
\left(\mathrm{kg} / \mathrm{m}^{3}\right)\end{array}$ & $\begin{array}{c}\text { POFA content } \\
\left(\mathrm{kg} / \mathrm{m}^{3}\right)\end{array}$ & \multicolumn{2}{c}{ Compressive strength (MPa) } \\
31-day
\end{tabular}

Note: MK: metakaolin; GGBS: ground granulated blast furnace slag; POFA: palm oil fuel ash.

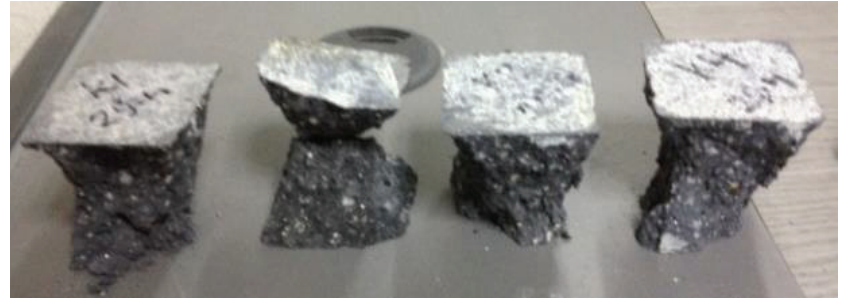

(a)

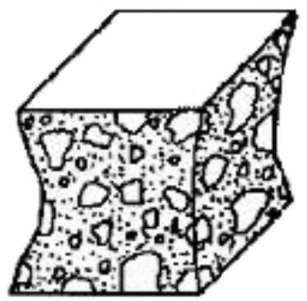

(b)

FIGURE 7: (a) Failure mode of cubes. (b) Satisfactory failures of BSEN 12390-3:2002.

\section{Results and Discussion}

3.1. Flow. The flow of mortar is shown in Figure 8, while the flow values are shown in Table 4. A lower flow ability of the mortar was observed for mix M5, which could be due to the higher percentage of POFA. POFA decreases the flow tendency because of the porous and spongy nature of the microstructure (Figure 9) [2] of these materials and an increased fineness or surface area. Figure 11 and Table 4 show that the flow percentage increased in mixes M16, M17, and M18, which could be attributed to a decrease in the percentage of POFA (Table 3 ) in the mortars. It is also observed in Figure 11 that the flow percentage increased with the increase in the MK percentage in the mortars because MK has a much finer particle size than POFA and GGBS and requires less water to obtain a flow [37]. Workability in geopolymer depends on the viscous properties of the binder matrix. $\mathrm{Si}$ plays major role in producing viscosity [13]. The percentage of $\mathrm{SiO}_{2}$ is not so much different between mixes M1 and M18; that is why the flow has no significant differences between each of the mixtures.

3.2. Oven Dry Density (ODD). The oven dry density (ODD) was taken for all specimens after oven-drying at a temperature of $65^{\circ} \mathrm{C}$ for a period of 24-h. Figure 10 and Table 4 show the 3-day oven dry density (ODD) of the specimens with different replacement levels of MK, GGBS, and POFA. The ODD of the mortar varied between $1639 \mathrm{~kg} / \mathrm{m}^{3}$ and $2181 \mathrm{~kg} / \mathrm{m}^{3}$. The spherical particles of all the materials, compared to the crushed particles in a wet state, could produce a higher packing density, resulting in lower water retention in the spherical case, and, consequently, lower water demand [38]. Thus, the use of a high percentage of GGBS with spherical particles produced the highest ODD of $2181 \mathrm{~kg} / \mathrm{m}^{3}$ among all the mixes. The POFA, due to its agglomerated and crushed shape and increasing interparticle friction particles, cannot easily roll over one another. Therefore, this highlights 
TABLE 4: Flow of mortar and 3-day average oven dry density (ODD) $\left(\mathrm{kg} / \mathrm{m}^{3}\right)$ of mortar for all mixes.

\begin{tabular}{|c|c|c|c|c|c|c|c|c|c|c|c|c|c|c|c|c|c|c|}
\hline & \multicolumn{18}{|c|}{ Mix number } \\
\hline & M1 & M2 & M3 & M4 & M5 & M6 & M7 & M8 & M9 & M10 & M11 & M12 & M13 & M14 & M15 & M16 & M17 & M18 \\
\hline Flow (\%) & 61 & 62 & 64 & 67 & 60 & 67 & 67 & 68 & 69 & 72 & 71 & 72 & 70 & 73 & 75 & 76 & 79 & 78 \\
\hline Density $\left(\mathrm{kg} / \mathrm{m}^{3}\right)$ & 1874 & 1789 & 1870 & 2115 & 1639 & 1896 & 2007 & 1691 & 1739 & 1756 & 1821 & 1914 & 2067 & 2181 & 1833 & 1943 & 2089 & 1961 \\
\hline
\end{tabular}

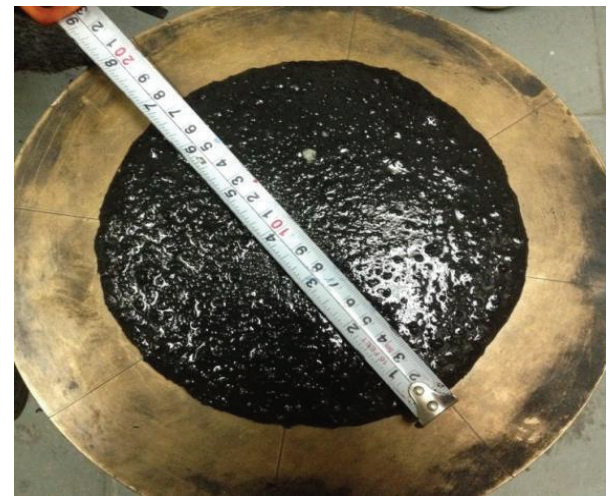

Figure 8: Flow of mortar.

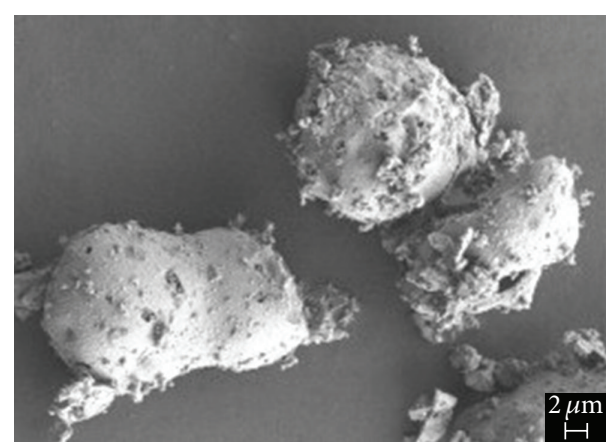

FIGURE 9: Field emission scanning electron microscopy (FESEM) images of POFA [2].

the need for more evaporable water in mixes with high POFA content in order to obtain a workable mix. Hence, the use of a higher dosage of POFA decreases the specimen density [2]. The use of $65 \%$ of POFA in mix 5 shows the lowest ODD of $1639 \mathrm{~kg} / \mathrm{m}^{3}$. Another factor that influences the density is the ability of finer particles to fill the voids within the mortar. Figure 3 shows that POFA has relatively coarser particles within a narrow range compared to that of GGBS and MK. Thus, a high percentage of GGBS (mix 14) with finer particles enhances its density by about $25 \%$ compared to mortar with a high percentage of POFA (mix 5). Khatib and Wild [39] reported that the threshold value for pastes decreased with the increase in MK content. The ODD of the mortar decreased slightly by about $2.2 \%$ in the first few weeks but remained almost constant thereafter. Figure 11 shows the reduction in density for all mixes (mix 14).

3.3. Compressive Strength Development. The development of the compressive strength of hardened geopolymer mortar

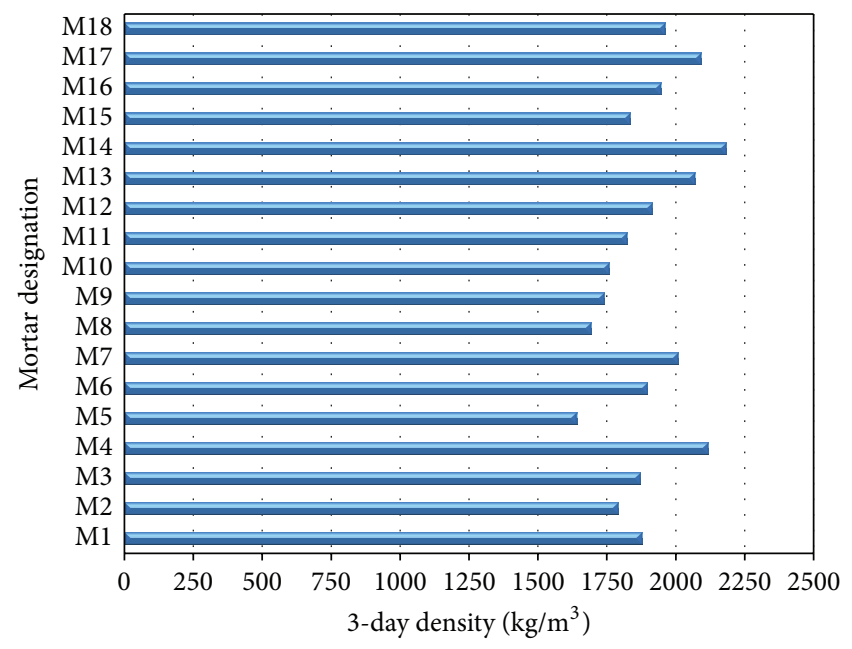

Figure 10: 3-day average density $\left(\mathrm{kg} / \mathrm{m}^{3}\right)$ for all mixes.

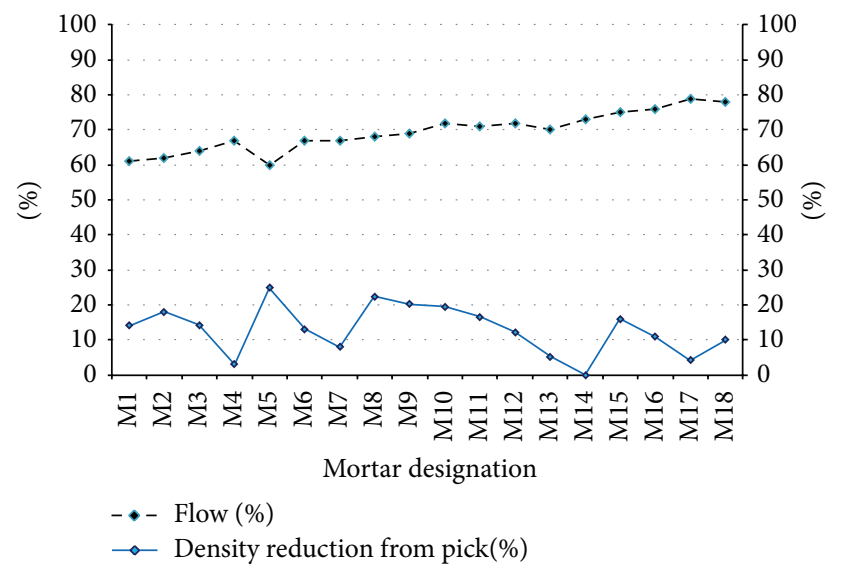

FIGURE 11: Density $\left(\mathrm{kg} / \mathrm{m}^{3}\right)$ reduction for all mixes from the peak of density and the percentage of flow of mortar.

is the basic indicator of the performance of alternative source materials, since it provides a fundamental description concerning the quality of geopolymerization products. The development of compressive strength at the ages of 3, 7, 14, and 28 days is shown in Figure 12. As indicated in the methodology, the specimens were cured at $65^{\circ} \mathrm{C}$ for $24-\mathrm{h}$. Curing at an elevated temperature allows a reduction in the time of heat treatment to achieve high strength [40]. It can be observed from Figure 12 that mix M1, which contained $5 \% \mathrm{MK}, 35 \%$ GGBS, and 60\% POFA and was cured at $65^{\circ} \mathrm{C}$ for $24-\mathrm{h}$, produced the lowest compressive strength. However, an increase in the MK from 5\% to $10 \%$ and 


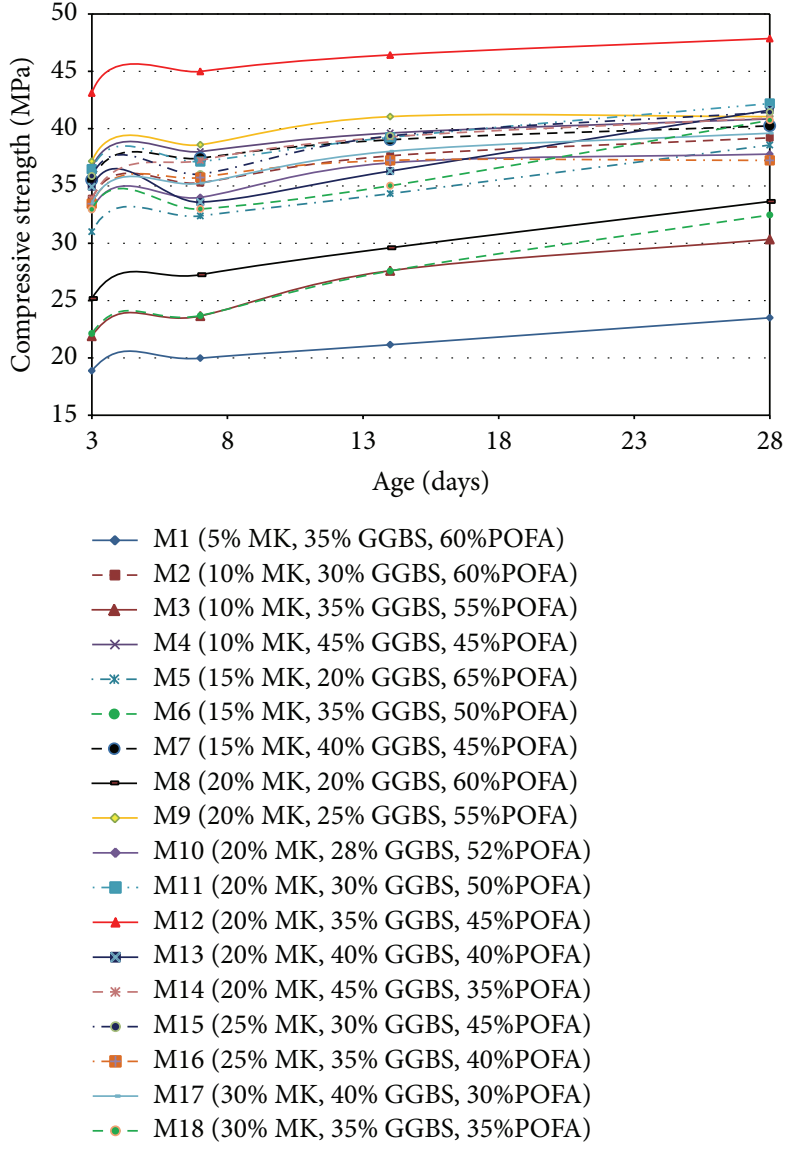

FIGURE 12: Compressive strength development of mortar at different ages with varying binder content ratios.

subsequent decrease in POFA in mix M3 showed an increase in the compressive strength. It can be seen that this trend continued until the MK was increased to $20 \%$. It was observed that with up to $20 \%$ replacement of MK by POFA the highest compressive strength of about $48 \mathrm{MPa}$ could be obtained. With any further increase in the MK content beyond $20 \%$, the strength decreased, as seen from the mixes M16 and M18, which had $25 \%$ and $30 \%$ of MK, respectively. A similar trend was observed for mixes with an increase in both the GGBS and POFA contents. Thus, it can be concluded that mix M12 with 20\% MK, 35\% GGBS, and 45\% POFA with high $\mathrm{SiO}_{2}$ and $\mathrm{Al}_{2} \mathrm{O}_{3}$ contents produced the highest compressive strength. It is evident that POFA contained fewer amounts of $\mathrm{Al}_{2} \mathrm{O}_{3}$ and $\mathrm{Ca}$, when mixed with GGBS, which enhanced the compressive strength. From the results, it is also observed that up to $45 \%$ of the binders could be replaced by POFA to achieve a compressive strength of $48 \mathrm{MPa}$. However, an increase of POFA beyond $45 \%$ had a negative effect on the compressive strength. Thus, the amount of $\mathrm{Ca}$ and $\mathrm{Al}_{2} \mathrm{O}_{3}$ had a significant influence on the compressive strength of the mortar [41]. From Figure 12, it can also be seen that the compressive strength curve is steep at the age of 3 days with a slight drop at 7 days, which may be because the Si/Al ratio varies during the geopolymerization process [42]. Table 5
TABLE 5: The percentage (\%) increase in the compressive strength at 3,7 , and 14 days compared with the 28 -day strength.

\begin{tabular}{lccc}
\hline $\begin{array}{l}\text { Mortar } \\
\text { designation }\end{array}$ & \multicolumn{3}{c}{ Increase of compressive strength (\%) } \\
3-day (\%) & 7-day (\%) & 14-day (\%) \\
\hline M1 & 80 & 85 & 90 \\
M2 & 87 & 90 & 96 \\
M3 & 72 & 78 & 91 \\
M4 & 90 & 93 & 97 \\
M5 & 80 & 84 & 89 \\
M6 & 68 & 73 & 85 \\
M7 & 88 & 93 & 97 \\
M8 & 75 & 81 & 88 \\
M9 & 91 & 94 & 100 \\
M10 & 87 & 90 & 98 \\
M11 & 86 & 88 & 93 \\
M12 & 90 & 94 & 97 \\
M13 & 84 & 87 & 94 \\
M14 & 83 & 91 & 96 \\
M15 & 87 & 87 & 95 \\
M16 & 90 & 96 & 100 \\
M17 & 85 & 89 & 96 \\
M18 & 81 & 81 & 86 \\
\hline
\end{tabular}

shows the increase in the compressive strength at 3, 7, and 14 days compared to 28 days expressed as a percentage. It can be seen from a comparison of the 3-day test results with the 28-day strength that most of the specimens achieved about $80 \%$ of the 28 -day strength. Correspondingly, the 7 -day and 14 -day strengths were $87 \%$ and $94 \%$, respectively, of the 28 day strength (Figure 15).

3.4. Analysis of Chemical Composition on the Development of Strength. The parameters, such as curing temperature, water content, alkali concentration, initial solids content, silicate and aluminate ratio, $\mathrm{pH}$, and the type of activators used, influence the rate of polymerization [13]. The comparison of the major oxide composition of the three materials, that is, MK, GGBS, and POFA, is shown in Table 6. As explained in Section 3.3, the mixes M1 and M12 produced the lowest and the highest compressive strengths, respectively. It can be seen from Table that the $\mathrm{SiO}_{2}$ content was found to be higher in mix M12 compared to the other mixes, for which the ratio of $\mathrm{Si} / \mathrm{Al}$ for $\operatorname{mix} \mathrm{M} 12$ was 3.26. In contrast, the $\mathrm{Si} / \mathrm{Al}$ ratio for $\mathrm{M} 1$ was found to be 5.12 . The initial Si/Al ratio will not be constant all the way through the geopolymerization process. During different stages of geopolymerization the $\mathrm{Si} / \mathrm{Al}$ ratio increases [42]. The trend of compressive strength development is affected by the change in the $\mathrm{Si} / \mathrm{Al}$ ratio in the original particles, the reactive ones, and the reacted product during the reaction process [43]. Geopolymerization was almost complete after 7 days and that the strength gain beyond this period was found to be insignificant. Lime $(\mathrm{CaO})$ plays a very important role as it controls the strength and soundness, whereas excess $\mathrm{CaO}$ 
TABLE 6: The major chemical components of mortar.

\begin{tabular}{|c|c|c|c|c|c|c|c|c|c|c|c|c|c|c|c|c|c|c|}
\hline \multirow{2}{*}{$\begin{array}{l}\text { Chemical } \\
\text { components }\end{array}$} & \multicolumn{18}{|c|}{ Mortar designation } \\
\hline & M1 & M2 & M3 & M4 & M5 & M6 & M7 & M8 & M9 & M10 & M11 & M12 & M13 & M14 & M15 & M16 & M17 & M18 \\
\hline & 18.68 & 16.42 & & 22.65 & 12.09 & 18.32 & 20.39 & & & & & & & & & & & 17.77 \\
\hline $\mathrm{SiO}_{2}$ & 52.01 & 52.97 & 51.43 & 48.34 & 55.48 & 50.84 & 49.3 & 54.89 & 53.35 & 52.42 & 51.8 & 50.26 & 48.71 & 47.17 & 51.22 & 49.67 & 47.54 & 49.09 \\
\hline $\mathrm{Al}_{2} \mathrm{O}_{3}$ & & & & & & 13.66 & & & & & & & & & & 17.17 & 19.33 & 18.92 \\
\hline $\mathrm{MgO}$ & 3.44 & 3.32 & & 3.25 & 3.23 & & & 3.09 & 3.07 & 305 & 3.04 & 3.02 & 3 & 2.97 & 2.9 & 2.88 & 2.72 & 2.74 \\
\hline $\mathrm{Fe}_{2} \mathrm{O}_{3}$ & & & & & 2.97 & & & & & & & & & & 2.27 & & & 1.92 \\
\hline $\mathrm{Na}_{2} \mathrm{O}$ & & & 0.21 & & & & 0.22 & 0.21 & 0.21 & 0.22 & 0.22 & & 0.23 & 0.23 & 0.22 & 0.23 & 0.24 & 0.24 \\
\hline $\mathrm{K}_{2} \mathrm{O}$ & 4.07 & 4.14 & 3.85 & 3.26 & 4.51 & 3.63 & 3.34 & 4.29 & 4 & 3.83 & 3.71 & 3.42 & 3.12 & 2.83 & 3.49 & 3.2 & 2.69 & 2.98 \\
\hline $\mathrm{SiO}_{2} / \mathrm{Al}_{2} \mathrm{O}_{3}$ & 5.12 & 4.61 & 4.32 & 3.8 & 4.46 & 3.72 & 3.5 & 3.87 & 3.65 & 3.53 & 3.45 & 3.26 & 3.08 & 2.91 & 3.06 & 2.89 & 2.46 & 2.59 \\
\hline
\end{tabular}

content makes the material unsound and causes expansion and disintegration. An excessive quantity of lime $(\mathrm{CaO})$ is considered for the hardening mechanism of mortar [44]. Mix M4 contained the highest percentage of $\mathrm{CaO}$ among all the mixes but produced the lowest compressive strength of about $37 \mathrm{MPa}$. The formation of $\mathrm{Ca}$ compounds in geopolymers is greatly dependent on the $\mathrm{pH}$ and $\mathrm{Si} / \mathrm{Al}$ ratio. The $\mathrm{SiO}_{2}$ content provides greater strength, but, at the same time, it extends the setting time [13]. Although mix M5 contained the highest percentage of $\mathrm{SiO}_{2}$ among all the mixes, the $\mathrm{Si} / \mathrm{Al}$ ratio was quite high (4.45). Further, mixes M5 and M1 contained high percentages of $\mathrm{K}_{2} \mathrm{O}$ and $\mathrm{MgO}$, respectively, which are harmful ingredients in cement. Mixes M17 and $\mathrm{M} 1$ contained the highest percentage of $\mathrm{Na}_{2} \mathrm{O}$ and $\mathrm{MgO}$. If the amount of $\mathrm{Na}_{2} \mathrm{O}$ and $\mathrm{K}_{2} \mathrm{O}$ exceeds $1 \%$, it leads to the failure of concrete and if the content of $\mathrm{MgO}$ exceeds $5 \%$, it causes cracks in the hardened concrete. Further, the $\mathrm{Al}$ component tends to dissolve easier than the Si components, which enables a higher rate of condensation between the silicate and aluminate species than the condensation between just the silicate species [45].

3.5. Effect of Metakaolin on the Compressive Strength. In general, $\mathrm{MK}$ is a poorly crystallized white powder with a specific surface of $12,000 \mathrm{~m}^{2} / \mathrm{kg}$ (Table 2) and an average particle size between 1.5 and $2.5 \mu \mathrm{m}$ [46]. MK is effective at reducing the rate of diffusion of the $\mathrm{Cl}^{-}$and $\mathrm{Na}^{+}$ions in mortar and also the rate of water absorption [47]. The effect of MK content on the compressive strength is shown in Figure 13. The results of Wild et al. [48] derived the maximum compressive strength possible at the different percentage replacements of MK. The use of $20 \% \mathrm{MK}$ with $45 \%$ of POFA and $35 \%$ of GGBS in mix M12 produced the highest strength of about $48 \mathrm{MPa}$. The mixes M1, M3, and M6 that contained 5\%, 10\%, and 15\% MK with 35\% GGBS and different amounts of POFA produced about 51\%, $37 \%$, and $32 \%$ lower compressive strength than mix M12. This is because $\mathrm{M} 12$ contained more $\mathrm{Al}_{2} \mathrm{O}_{3}$ compared to the other mixes. Al plays an important role, as, to a large degree, it controls the properties of geopolymers, and the

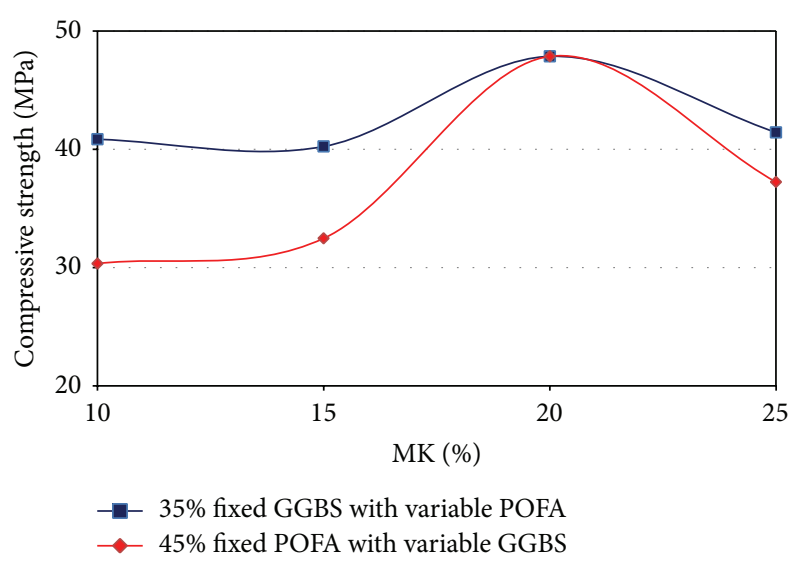

FIGURE 13: Effect of MK on compressive strength mixed with 45\% POFA and 35\% GGBS.

absolute amount of available $\mathrm{Al}$ throughout the reaction affects the final compressive strength [49]. Similarly, for mixes M7 and M14, which contained 15\% MK, 40\% GGBS, and $45 \%$ POFA and 20\% MK, 45\% GGBS, and 35\% POFA, respectively, the compressive strength decreased by $16 \%$ and $15 \%$ compared to mix M12. MK grains are not fully dissolved during the geopolymerization process as the reaction takes place on the surface layer of the solid particles [50]. The reaction rate is then mainly controlled by diffusion of the hydroxide and silicate ions through the primary geopolymer gel, which is mainly affected by the curing temperature at the early stage of the reaction. In the case of increasing the percentage of $\mathrm{MK}$, the compressive strength also reduced compared to mix M12. The inclusion of a small amount of MK in GGBS-rich alkali silicate-activated binders produces stable Al-substituted calcium silicate hydrate $(\mathrm{C}-\mathrm{S}-\mathrm{H})$ gels and promotes enhanced workability. A low activator content does not provide sufficient alkalinity to promote the dissolution of MK to produce a highly stable coexisting geopolymer gel. Therefore, a large proportion of MK needs activator content with very high concentration that will affect the 
rate of polymerization. Thus, the inclusion of MK after $20 \%$ reduces the compressive strength. Mixes M16 and M18, which contained $25 \% \mathrm{MK}, 35 \%$ GGBS, and $40 \%$ POFA and $30 \%$ MK, 35\% GGBS, and 35\% POFA, showed a reduction in the compressive strength by about $22 \%$ and $15 \%$ compared to M12. According to Austell [51] the rate of water absorption of mortar is halved by replacing $20 \%$ of MK. So, mix M12 with $20 \%$ MK, 35\% GGBS, and 45\% POFA produced the highest compressive strength and is considered the optimum mix to develop geopolymer mortar with a compressive cube strength of $40 \mathrm{MPa}$. Wild et al. [52] reported that increasing the specific surface of MK from 12,000 to $15,000 \mathrm{~m}^{2} / \mathrm{kg}$ reduces the age at which the maximum strength enhancement occurs in MK mortar. The effect of MK on the compressive strength at 28 days with $35 \%$ GGBS and $45 \%$ POFA is shown in Figure 13. One of the reasons for mixing MK with GGBS in this study is to provide better control of the setting time. GGBS binders have a tendency to set extremely rapidly and the addition of a small amount of MK can retard setting to provide a more convenient period of workability.

3.6. Effect of GGBS on the Compressive Strength. GGBS plays an important role for compressive strength development. A higher concentration of GGBS results in a higher compressive strength of geopolymer concrete [53]. GGBS contains higher $\mathrm{CaO}$, and, as a result, it is a good potential source of soluble $\mathrm{Ca}$ in the mixture. The compressive strength of mortar is shown in Figure 12. Mix number M12, with 35\% GGBS, produced the highest strength, while a further decrease in the GGBS content reduced the compressive strength. M11 (30\% GGBS with $20 \%$ MK, 50\% POFA) and M9 (25\% GGBS with 20\% MK, 55\% POFA) showed a decrease in strength of about $12 \%$ and $14 \%$ with respect to M12. Yunsheng et al. [54] also reported that the addition of GGBS leads to a considerable increase in the compressive strength but only when the GGBS replacement percentage exceeds $30 \%$. GGBS is a latent hydraulic product, which can be activated by suitable activators, and, without activation, the development of the strength of the GGBS is extremely slow and the development of the slag necessitates a pHP12 [44]. Mix M13 contained 40\% GGBS with 20\% MK, 40\% POFA, while mix M12 contained 35\% GGBS with $20 \% \mathrm{MK}, 45 \%$ POFA. A comparison between mixes M12 and M13 showed that the former with $40 \%$ GGBS produced $13 \%$ lower compressive strength compared to the mix with 35\% GGBS and that mix M14 with 45\% GGBS showed that the reduction is $15 \%$. Therefore, if the percentage of GGBS exceeds $35 \%$, then the compressive strength also reduces. This might be because the GGBS undergoes a slower hydration process; therefore at higher GGBS replacement levels, the hydration process becomes increasingly slower, which leads to a reduction in the compressive strength [55]. Another reason is that the quantity of soluble Ca depends on the volume of GGBS present in the mixture, which has a direct effect on the compressive strength. Figure 14 shows the effect of GGBS on the compressive strength with POFA and 20\% MK.

3.7. Effect of POFA on the Compressive Strength. POFA, which is also a by-product from thermal power plants, contains

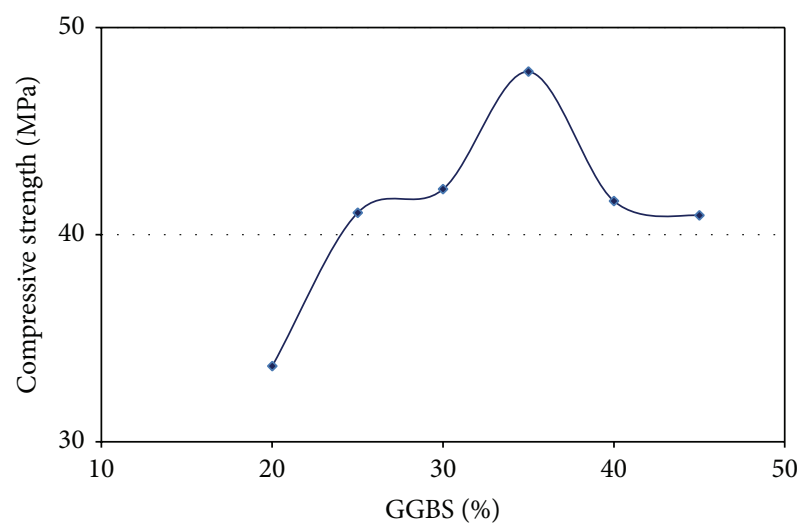

FIGURE 14: Effect of GGBS on compressive strength mixed with POFA and $20 \%$ fixed MK.

high amounts of $\mathrm{Si}$ and $\mathrm{Al}$ oxides in the amorphous state and is considered to be a pozzolanic material [56]. The high fineness of POFA produces a greater pozzolanic reaction and acts as a filler in the voids and thus increases the compressive strength of the concrete [21]. Figure 16 shows the effect of varying POFA contents on the compressive strength with MK varying from $5 \%$ to $30 \%$ with nonvarying GGBS at $35 \%$. The compressive strengths of mixes M1 and M3, which contained 60\% POFA and 55\% POFA, respectively, produced about $51 \%$ and $37 \%$ lower compressive strength than mix M12. Mix M12 with 45\% of POFA, 35\% of GGBS, and 20\% MK produced the highest strength of $48 \mathrm{MPa}$. Ariffin et al. [57] opined that due to its low content of $\mathrm{Al}_{2} \mathrm{O}_{3}$ it 0produces low compressive strength; the use of high POFA content could be attributed to the incomplete geopolymerization, because $\mathrm{Al}_{2} \mathrm{O}_{3}$ tends to dissolve at a higher rate during the early stage of geopolymerization. The comparison between mixes M12 and M13 showed that the former with 40\% POFA produced $13 \%$ lower compressive strength compared to the mix with $45 \%$ POFA. Then, from the comparison between mixes M12 and M14 (35\% POFA), the strength reduced by about 15\% for the latter.

The particles of the POFA with cohesive characteristics could not be mixed properly, and, hence, the strength development was poor. Tonnayopas et al. [58] explained that the low early compressive strength is due to the slow pozzolanic activity of POFA. Figure 14 shows the 28 days' compressive strength of all mixes.

3.8. Effect of Curing. All the specimens were covered with plastic wrapping and cured in an oven at $65^{\circ} \mathrm{C}$ for $24 \mathrm{~h}$, as stated in the methodology; the results for the compressive strengths are shown in Figure 12. The average difference between the 14- and 28-day compressive strength for the mixes was about $10 \%$, and, between the 7- and 14-day strengths, it was $8 \%$. This shows that the rate of the geopolymerization is accelerated by elevated temperature at the early stage [59]. Kusbiantoro et al. [60] reported that compared to the other curing methods-ambient and external exposurethe oven-cured geopolymer concrete at $65^{\circ} \mathrm{C}$ exhibited superior mechanical properties. They reasoned that this could 


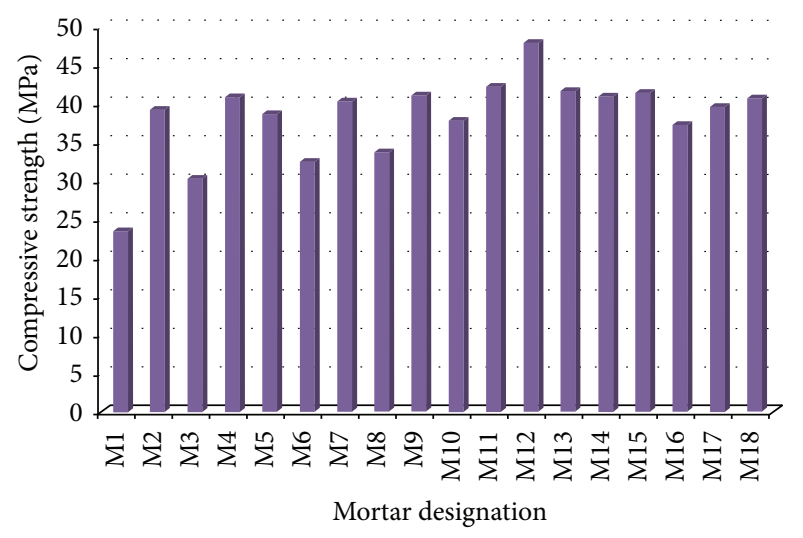

FIGURE 15: 28-day compressive strength of different mixes.

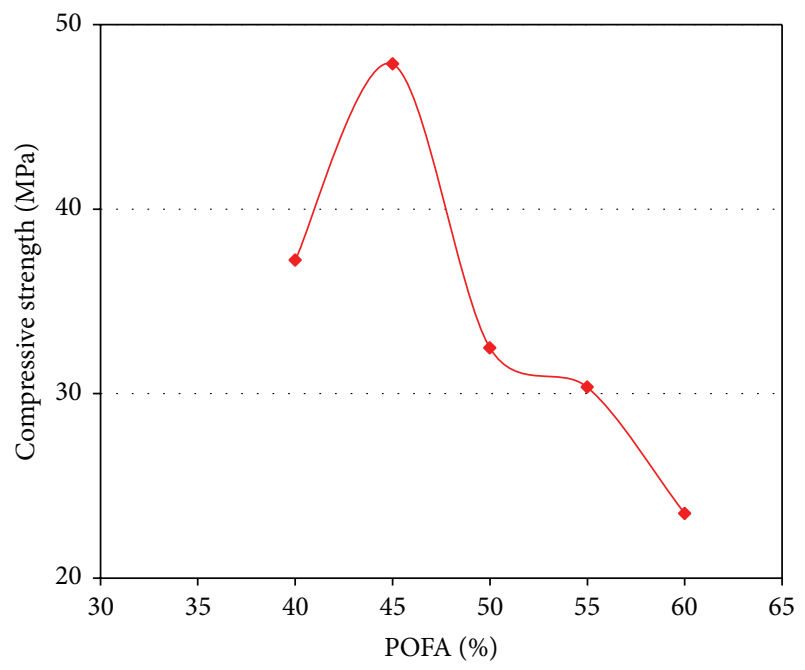

FIGURE 16: Effect of POFA on compressive strength mixed with MK and $35 \%$ fixed GGBS.

be attributed to the oven curing as the suitable condition to accelerate the dissolution and polycondensation of alumina silicate gel in the geopolymer framework. Furthermore, geopolymer concrete could achieve high early compressive strength when oven-cured, instead of undergoing ambient curing [61]. Hence, all the mixes, M1 to M18, gathered maximum strength within 3 days, as shown in Table 5 .

3.9. Alkaline Solution to Binder Ratio by Mass on Compressive Strength Analysis. The solution to binder ratio was kept constant at 0.5 for all the mixtures, as stated in Table 4. Abdullah et al. [62] reported that the ratio of S/B of 0.5 by mass produces higher compressive strength compared to the ratio of 0.67. Sathonsaowaphak et al. [63] found a very low compressive strength of $8 \mathrm{MPa}$ for the mix with the AK/B ratio of 0.325 by mass; however, they reported that the high compressive strengths were in the range of 42 to $52 \mathrm{MPa}$, as the ratios of S/B by mass varied between 0.429 and 0.709 . Thus, the use of a solution to binder ratio of 0.5 for all the mixtures produced acceptable compressive strength.
3.10. Effect of Molarity of Alkaline Activated Solution ( $\mathrm{NaOH}$ Solution) on the Compressive Strength. Table 7 shows the effect of molarity of alkaline activated solution on the compressive strength.

The compressive strength of mix M4 with 14 molarities produced $17 \%$ higher than the mix M4A with 12 molarities. Other parameters except the molarity, such as binder, sand, and water, were kept constant for both the mixes. The use of high molarity based alkaline solution increases the compressive strength because of the release of silica and alumina [64]. From Figure 17 it was also found that the mixes M9, M12, and M16 with 14 molarities show higher compressive strength than the mixes M9A, M12A, and M16A with 12 molarities. All the parameters are same, respectively, except the molarity ( $\mathrm{NaOH}$ solution). $\mathrm{NaOH}$ solution with high concentration increases the geopolymerization reaction [43].

\section{Conclusions}

This research into optimizing the use of MK, GGBS, and POFA as binders in the production of geopolymer mortars produced significant conclusions. Twenty-four geopolymer mortar mixtures incorporating sustainable binders-MK, GGBS, and POFA-were prepared. The cube compressive strength of the mortars was investigated up to a period of 28 days to study the feasibility of the replacement with GGBS and POFA in MK-based geopolymer mortar. Based on the tests conducted, the following conclusions were drawn:

(i) The compressive strength of the geopolymer mortar increased with the MK content up to $20 \%$, while further replacement of MK showed a significant reduction in the strength.

(ii) Mix M12, with the addition of GGBS up to 35\%, POFA up to $45 \%$ with $20 \%$ MK, produced the highest strength among the mixes.

(iii) It is possible to improve the compressive strength of the geopolymer mortars at the early ages by introducing initial heating at $65^{\circ} \mathrm{C}$ for $24 \mathrm{~h}$ after demoulding. Improvements are more significant at 3 days.

(iv) In most of the specimens, $90 \%$ of the compressive strength of the geopolymer mortar was achieved at the age of 7 days.

(v) POFA produces a cohesive mix, in which the density of mortar decreases with the increase in the percentage of POFA, resulting in a decrease in density of approximately $12 \%$.

(vi) The finer particles of GGBS produce a dense mix; hence, the partial substitution of GGBS in the mortar should be maintained at $35 \%$.

(vii) The compressive strength increases with the increases of molarity of sodium hydroxide solution.

(viii) It can also be concluded that the combined maximum volumes of MK, GGBS, and POFA can be used for the development of a sustainable construction material to replace OPC for the production of ecoenvironmentally friendly geopolymer mortars. 
TABLE 7: Comparison of the compressive strength between different molarities.

\begin{tabular}{|c|c|c|c|c|c|}
\hline \multirow{2}{*}{ Mortar designation } & \multirow{2}{*}{$\begin{array}{l}\text { Binder mix proportion } \\
\text { MK/GGBS/POFA (\%) }\end{array}$} & \multirow{2}{*}{$\begin{array}{l}\text { M-sand } \\
\left(\mathrm{kg} / \mathrm{m}^{3}\right)\end{array}$} & \multirow{2}{*}{$\begin{array}{c}\text { Alkali activator } \\
\text { molarity }\end{array}$} & \multicolumn{2}{|c|}{ Compressive strength $(\mathrm{MPa})$} \\
\hline & & & & 3-day & 28-day \\
\hline M4 & $10 / 45 / 45$ & 1532 & 14 & 36.6 & 40.85 \\
\hline M6 & $15 / 35 / 50$ & 1532 & 14 & 22.15 & 32.5 \\
\hline M9 & $20 / 25 / 55$ & 1532 & 14 & 37.15 & 41 \\
\hline M12 & $20 / 35 / 45$ & 1532 & 14 & 43.15 & 48 \\
\hline M16 & $25 / 35 / 40$ & 1532 & 14 & 33.4 & 37.5 \\
\hline M18 & $30 / 35 / 35$ & 1532 & 14 & 34 & 40.8 \\
\hline M4A & $10 / 45 / 45$ & 1532 & 12 & 30.8 & 34.1 \\
\hline M6A & $15 / 35 / 50$ & 1532 & 12 & 17.2 & 25.8 \\
\hline M9A & $20 / 25 / 55$ & 1532 & 12 & 32.5 & 37 \\
\hline M12A & $20 / 35 / 45$ & 1532 & 12 & 36 & 41.5 \\
\hline M16A & $25 / 35 / 40$ & 1532 & 12 & 27.6 & 33 \\
\hline M18A & $30 / 35 / 35$ & 1532 & 12 & 31.1 & 35.6 \\
\hline
\end{tabular}

Note: MK: metakaolin; GGBS: ground granulated blast furnace slag; POFA: palm oil fuel ash.

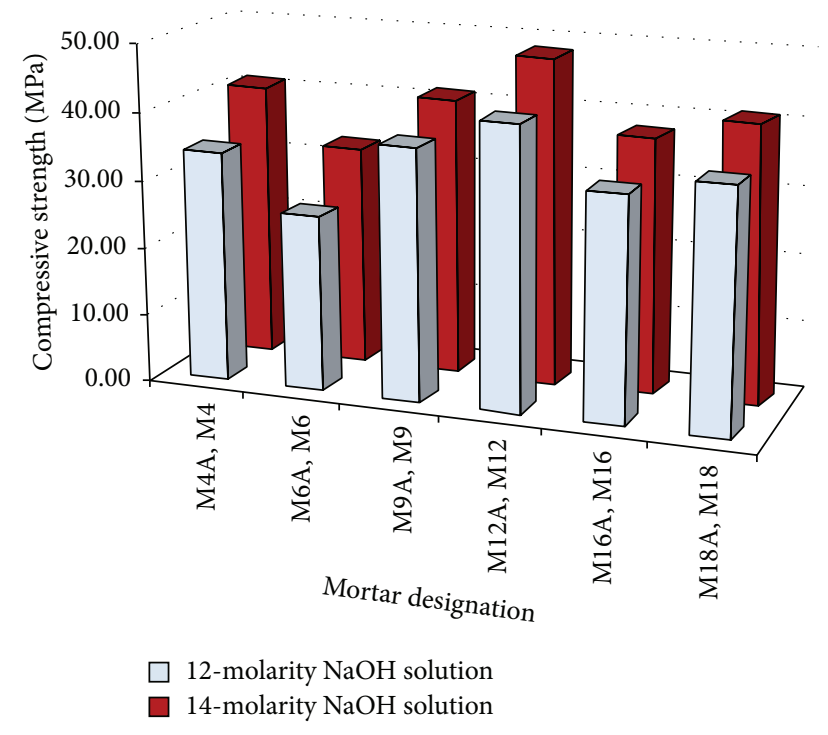

FIGURE 17: Effect of molarity in compressive strength.

This research work was focused on the development of the compressive strength of geopolymer mortar produced by different proportion of three pozzolanic materials and activated by two concentrated alkaline solutions. The test results were analysed based on the chemical compositions. Geopolymerization process could be affected by the particle size and reactivity rate of the binding materials, curing condition, and casting process. This could be recommended for further research work on the microstructural analysis for the proposed binding materials with different particle size and various curing conditions. Since water/binder ratio is an important factor and affects significantly the development of compressive strength for different proportion of binder/aggregate in concrete and mortar, mix design with different type and volume of aggregate could be carried on for optimization.

\section{Conflict of Interests}

The authors declare that there is no conflict of interests regarding the publication of this paper.

\section{Acknowledgment}

The authors are grateful to the University of Malaya for the financial support through the University of Malaya Research Project "RP018/2012B: Development of Geopolymer Concrete for Structural Application."

\section{References}

[1] I. I. Bashar, U. J. Alengaram, M. Z. Jumaat, and A. Islam, "The effect of variation of molarity of alkali activator and fine aggregate content on the compressive strength of the fly ash: palm oil fuel ash based geopolymer mortar," Advances in Materials Science and Engineering, vol. 2014, Article ID 245473, 13 pages, 2014.

[2] N. Ranjbar, M. Mehrali, A. Behnia, U. J. Alengaram, and M. Z. Jumaat, "Compressive strength and microstructural analysis of fly ash/palm oil fuel ash based geopolymer mortar," Materials and Design, vol. 59, pp. 532-539, 2014.

[3] R. H. Kupaei, U. J. Alengaram, and M. Z. Jumaat, "The effect of different parameters on the development of compressive strength of oil palm shell geopolymer concrete," The Scientific World Journal, vol. 2014, Article ID 898536, 16 pages, 2014.

[4] P. Chana, "Low carbon cements: the challenges and opportunities," in Proceedings of the Future Cement Conference and Exhibition, pp. 8-9, London, UK, February 2011.

[5] L. G. Communications, Sustainability Report 2013, Lafarge, 2013.

[6] J. Davidovits, "Global warming impact on the cement and aggregates industries," World Resource Review, vol. 6, no. 2, pp. 263-278, 1994

[7] E. Worrell, L. Price, N. Martin, C. Hendriks, and L. O. Meida, "Carbon dioxide emissions from the global cement industry," 
Annual Review of Energy and the Environment, vol. 26, no. 1, pp. 303-329, 2001.

[8] D. M. Roy and G. M. Idorn, "Hydration, structure, and properties of blast furnace slag cements, mortars, and concrete," ACI Journal Proceedings, vol. 79, no. 6, pp. 444-457, 1982.

[9] L. K. Turner and F. G. Collins, "Carbon dioxide equivalent (CO2-e) emissions: a comparison between geopolymer and OPC cement concrete," Construction and Building Materials, vol. 43, pp. 125-130, 2013.

[10] J. L. Provis and J. S. J. van Deventer, "Geopolymerisation kinetics. 1. In situ energy-dispersive X-ray diffractometry," Chemical Engineering Science, vol. 62, no. 9, pp. 2309-2317, 2007.

[11] J. Davidovits, "Geopolymer chemistry and sustainable development. The poly (sialate) terminology: a very useful and simple model for the promotion and understanding of greenchemistry," in Proceedings of the Geopolymer Conference, pp. 915, Saint Quentin, France, September 2005.

[12] P. Duxson, G. C. Lukey, and J. S. J. Van Deventer, "Physical evolution of Na-geopolymer derived from metakaolin up to $1000^{\circ}$ C, Journal of Materials Science, vol. 42, no. 9, pp. 30443054, 2007.

[13] A. Islam, U. J. Alengaram, M. Z. Jumaat, and I. I. Bashar, "The development of compressive strength of ground granulated blast furnace slag-palm oil fuel ash-fly ash based geopolymer mortar," Materials \& Design, vol. 56, pp. 833-841, 2014.

[14] J. L. Provis and J. S. J. van Deventer, Geopolymers: Structures, Processing, Properties and Industrial Applications, Elsevier, 2009.

[15] J. L. Provis, "Geopolymers and other alkali activated materials: why, how, and what?" Materials and Structures, vol. 47, no. 1-2, pp. 11-25, 2014.

[16] D. Hardjito, S. E. Wallah, D. M. J. Sumajouw, and B. V. Rangan, "On the development of fly ash-based geopolymer concrete," ACI Materials Journal, vol. 101, no. 6, pp. 467-472, 2004.

[17] E. I. Diaz, E. N. Allouche, and S. Eklund, "Factors affecting the suitability of fly ash as source material for geopolymers," Fuel, vol. 89, no. 5, pp. 992-996, 2010.

[18] J. Davidovits, "Properties of geopolymer cements," in Proceedings of the 1st International Conference on Alkaline Cements and Concretes, pp. 131-149, Kiev, Ukraine, 1994.

[19] H. Tchakoute Kouamo, A. Elimbi, J. A. Mbey, C. J. Ngally Sabouang, and D. Njopwouo, "The effect of adding aluminaoxide to metakaolin and volcanic ash on geopolymer products: a comparative study," Construction and Building Materials, vol. 35, pp. 960-969, 2012.

[20] S. A. Bernal, E. D. Rodríguez, R. Mejía De Gutiérrez, M. Gordillo, and J. L. Provis, "Mechanical and thermal characterisation of geopolymers based on silicate-activated metakaolin/slag blends," Journal of Materials Science, vol. 46, no. 16, pp. 5477-5486, 2011.

[21] W. Tangchirapat, T. Saeting, C. Jaturapitakkul, K. Kiattikomol, and A. Siripanichgorn, "Use of waste ash from palm oil industry in concrete," Waste Management, vol. 27, no. 1, pp. 81-88, 2007.

[22] A. S. M. A. Awal and M. W. Hussin, "The effectiveness of palm oil fuel ash in preventing expansion due to alkali-silica reaction," Cement and Concrete Composites, vol. 19, no. 4, pp. 367-372, 1997.

[23] U. J. Alengaram, H. Mahmud, and M. Z. Jumaat, "Enhancement and prediction of modulus of elasticity of palm kernel shell concrete," Materials \& Design, vol. 32, no. 4, pp. 2143-2148, 2011.

[24] K. H. Mo, U. J. Alengaram, and M. Z. Jumaat, "A review on the use of agriculture waste material as lightweight aggregate for reinforced concrete structural members," Advances in Materials Science and Engineering, vol. 2014, Article ID 365197, 9 pages, 2014.

[25] W. Tangchirapat, S. Khamklai, and C. Jaturapitakkul, "Use of ground palm oil fuel ash to improve strength, sulfate resistance, and water permeability of concrete containing high amount of recycled concrete aggregates," Materials \& Design, vol. 41, pp. 150-157, 2012.

[26] J. Cai, Research of Effects and Mechanism of Micro Fines on Manufactured Fine Aggregate Concrete, Wuhan University of Technology, Wuhan, China, 2006.

[27] P. Nanthagopalan and M. Santhanam, "Fresh and hardened properties of self-compacting concrete produced with manufactured sand," Cement and Concrete Composites, vol. 33, no. 3, pp. 353-358, 2011.

[28] T.-L. Weng, W.-T. Lin, and A. Cheng, "Effect of metakaolin on strength and efflorescence quantity of cement-based composites," The Scientific World Journal, vol. 2013, Article ID 606524, 11 pages, 2013.

[29] A. Hawa, D. Tonnayopas, and W. Prachasaree, "Performance evaluation and microstructure characterization of metakaolinbased geopolymer containing oil palm ash," The Scientific World Journal, vol. 2013, Article ID 857586, 9 pages, 2013.

[30] U. J. Alengaram, B. A. A. Muhit, and M. Z. B. Jumaat, "Utilization of oil palm kernel shell as lightweight aggregate in concrete-a review," Construction and Building Materials, vol. 38, pp. 161-172, 2013.

[31] R. Sahana, "Setting time compressive strength and microstructure of geopolymer paste," in Proceedings of the International Conference on Energy and Environment (ICEE '13), vol. 2, December 2013, An ISO 3297:2007 Certified Organization.

[32] P. S. Deb, P. Nath, and P. K. Sarker, "The effects of ground granulated blast-furnace slag blending with fly ash and activator content on the workability and strength properties of geopolymer concrete cured at ambient temperature," Materials \& Design, vol. 62, pp. 32-39, 2014.

[33] R. H. Kupaei, U. J. Alengaram, M. Z. B. Jumaat, and H. Nikraz, "Mix design for fly ash based oil palm shell geopolymer lightweight concrete," Construction and Building Materials, vol. 43, pp. 490-496, 2013.

[34] D. Hardjito and B. V. Rangan, Development and Properties of Low-Calcium Fly Ash-Based Geopolymer Concrete, Curtin University of Technology, Perth, Australia, 2005.

[35] P. Chindaprasirt, T. Chareerat, and V. Sirivivatnanon, "Workability and strength of coarse high calcium fly ash geopolymer," Cement and Concrete Composites, vol. 29, no. 3, pp. 224-229, 2007.

[36] International A, "Standard test method for flow of hydraulic cement mortar," ASTM C1437-13, ASTM International, West Conshohocken, Pa, USA, 2013.

[37] A. S. Gill and R. Siddique, "Strength Properties and Sulphate Resistance of Self-Compacting Concrete Incorporating Silica Fume and Metakolin," 2012.

[38] E. Sakai, S. Hoshino, Y. Ohba, and M. Daimon, "The fluidity of cement paste with various types of inorganic powders," in Proceedings of the 10th International Congress on the Chemistry of Cement, Gothenburg, Sweden, June 1997.

[39] J. M. Khatib and S. Wild, "Sulphate resistance of metakaolin mortar," Cement and Concrete Research, vol. 28, no. 1, pp. 8392, 1998. 
[40] T. Bakharev, "Geopolymeric materials prepared using Class F fly ash and elevated temperature curing," Cement and Concrete Research, vol. 35, no. 6, pp. 1224-1232, 2005.

[41] D. Khale and R. Chaudhary, "Mechanism of geopolymerization and factors influencing its development: a review," Journal of Materials Science, vol. 42, no. 3, pp. 729-746, 2007.

[42] A. Fernández-Jiménez, A. Palomo, and M. Criado, "Microstructure development of alkali-activated fly ash cement: a descriptive model," Cement and Concrete Research, vol. 35, no. 6, pp. 1204-1209, 2005.

[43] X. Guo, H. Shi, and W. A. Dick, "Compressive strength and microstructural characteristics of class C fly ash geopolymer," Cement and Concrete Composites, vol. 32, no. 2, pp. 142-147, 2010.

[44] J. Davidovits, Geopolymer Chemistry and Applications, Geopolymer Institute, 2008.

[45] P. D. Silva, K. Sagoe-Crenstil, and V. Sirivivatnanon, "Kinetics of geopolymerization: role of $\mathrm{Al}_{2} \mathrm{O}_{3}$ and $\mathrm{SiO}_{2}$," Cement and Concrete Research, vol. 37, no. 4, pp. 512-518, 2007.

[46] M. A. Caldarone, K. A. Gruber, and R. G. Burg, "High-reactivity metakaolin: a new generation mineral admixture," Concrete International, vol. 16, no. 11, pp. 37-40, 1994.

[47] J. Kostuch, V. Walters, and T. Jones, "High performance concretes incorporating metakaolin: a review," Concrete, vol. 2, no. 1993, pp. 1799-1811, 2000.

[48] S. Wild, J. M. Khatib, and A. Jones, "Relative strength, pozzolanic activity and cement hydration in superplasticised metakaolin concrete," Cement and Concrete Research, vol. 26, no. 10, pp. 1537-1544, 1996.

[49] C. Li, H. Sun, and L. Li, "A review: the comparison between alkali-activated slag $(\mathrm{Si}+\mathrm{Ca})$ and metakaolin $(\mathrm{Si}+\mathrm{Al})$ cements," Cement and Concrete Research, vol. 40, no. 9, pp. 1341-1349, 2010.

[50] V. F. F. Barbosa, K. J. D. MacKenzie, and C. Thaumaturgo, "Synthesis and characterisation of materials based on inorganic polymers of alumina and silica: sodium polysialate polymers," International Journal of Inorganic Materials, vol. 2, no. 4, pp. 309-317, 2000.

[51] S. Austell, A New Pozzolanic Material for the Cement and Concrete Industry, Use of Metastar for the Production of Highly Durable Concretes and Mortars, ECC International product document, ECC International, Wareham, UK, 3rd edition, 1996.

[52] S. Wild, J. Khatib, and M. Craythorne, "Strength development of mortar containing metakaolin," in Proceedings of the 5th International Conference on Modern Building Materials, Structure and Techniques, pp. 58-63, Vilnius, Lituania, May 1997.

[53] N. P. Ganapati, A. S. S. N. Prasad, S. Adiseshu, and P. V. V. Satayanarayana, "A study on strength properties of geopolymer concrete with addition of G.G.B.S," International Journal of Engineering Research and Development, vol. 2, no. 4, pp. 19-28, 2012.

[54] Z. Yunsheng, S. Wei, C. Qianli, and C. Lin, "Synthesis and heavy metal immobilization behaviors of slag based geopolymer," Journal of Hazardous Materials, vol. 143, no. 1-2, pp. 206-213, 2007.

[55] K. H. Mo, U. J. Alengaram, and M. Z. Jumaat, "Utilization of ground granulated blast furnace slag as partial cement replacement in lightweight oil palm shell concrete," Materials and Structures, 2014.

[56] M. W. Hussin and A. S. M. Abdul Awal, "Influence of palm oil fuel ash on sulfate resistance of mortar and concrete," ACI Special Publication, vol. 178, pp. 417-430, 1998.
[57] M. A. M. Ariffin, M. W. Hussin, and M. A. R. Bhutta, "Mix design and compressive strength of geopolymer concrete containing blended ash from agro-industrial wastes," Advanced Materials Research, vol. 339, no. 1, pp. 452-457, 2011.

[58] D. Tonnayopas, F. Nilrat, K. Putto, and J. Tantiwitayawanich, "Effect of oil palm fiber fuel ash on compressive strength of hardening concrete," in Proceedings of the 4th Thailand Materials Science and Technology Conference, pp. 1-3, Pathumthani, Thailand, 2006.

[59] J. C. Swanepoel and C. A. Strydom, "Utilisation of fly ash in a geopolymeric material," Applied Geochemistry, vol. 17, no. 8, pp. 1143-1148, 2002.

[60] A. Kusbiantoro, M. F. Nuruddin, N. Shafiq, and S. A. Qazi, "The effect of microwave incinerated rice husk ash on the compressive and bond strength of fly ash based geopolymer concrete," Construction and Building Materials, vol. 36, pp. 695703, 2012.

[61] S. Wallah and B. V. Rangan, "Low calcium fly ash based geopolymer concrete-long term properties," Research Report GC1, Curtin University, Perth, Australia, 2006.

[62] M. M. A. Abdullah, H. Kamarudin, H. Mohammed, I. Khairul Nizar, A. R. Rafiza, and Y. Zarina, "The relationship of $\mathrm{NaOH}$ molarity, $\mathrm{Na}_{2} \mathrm{SiO}_{3} / \mathrm{NaOH}$ ratio, fly ash/alkaline activator ratio, and curing temperature to the strength of fly ash-based geopolymer," Advanced Materials Research, vol. 328-330, pp. 1475-1482, 2011.

[63] A. Sathonsaowaphak, P. Chindaprasirt, and K. Pimraksa, "Workability and strength of lignite bottom ash geopolymer mortar," Journal of Hazardous Materials, vol. 168, no. 1, pp. 4450, 2009.

[64] P. Chindaprasirt, C. Jaturapitakkul, W. Chalee, and U. Rattanasak, "Comparative study on the characteristics of fly ash and bottom ash geopolymers," Waste Management, vol. 29, no. 2, pp. 539-543, 2009. 

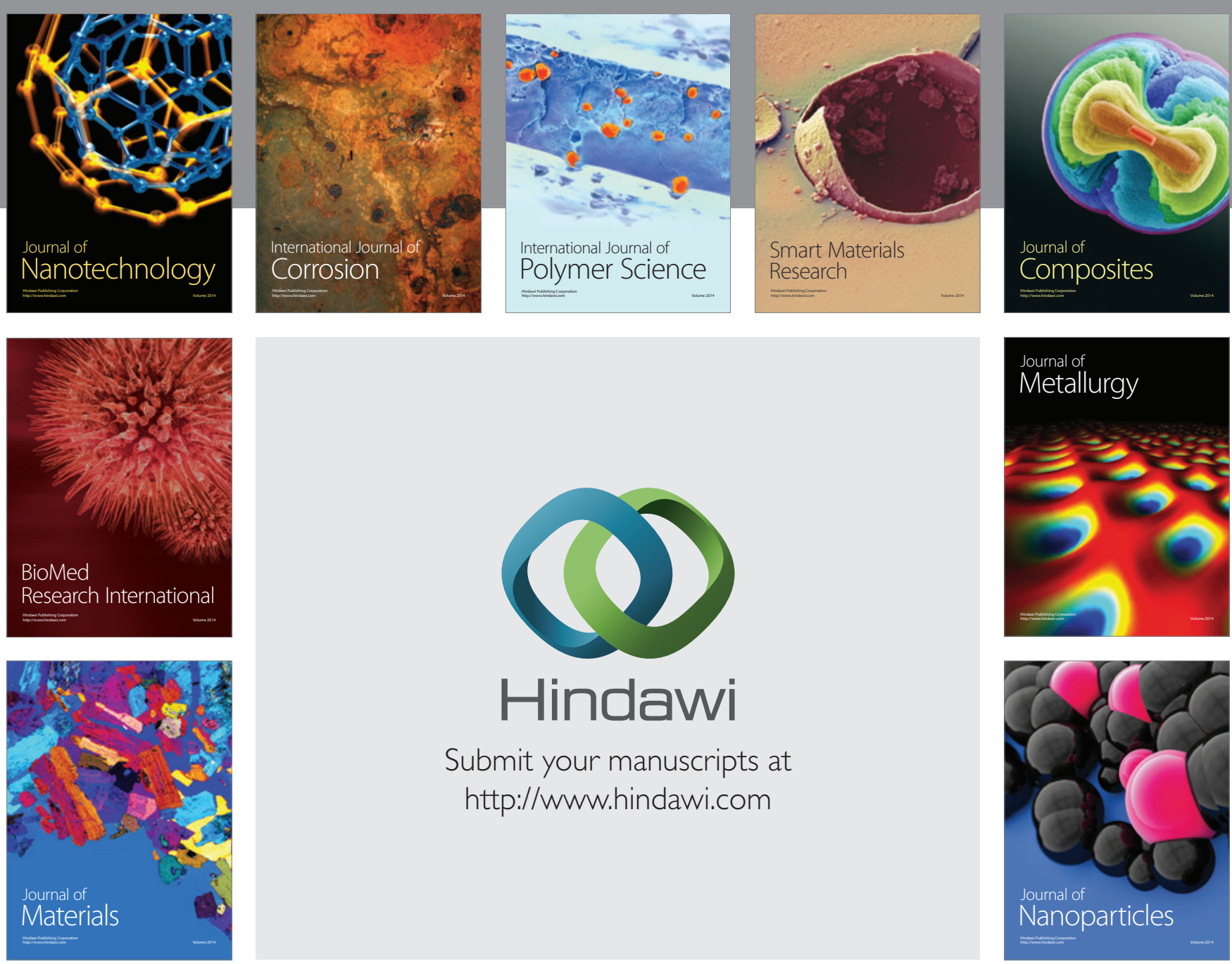

Submit your manuscripts at http://www.hindawi.com
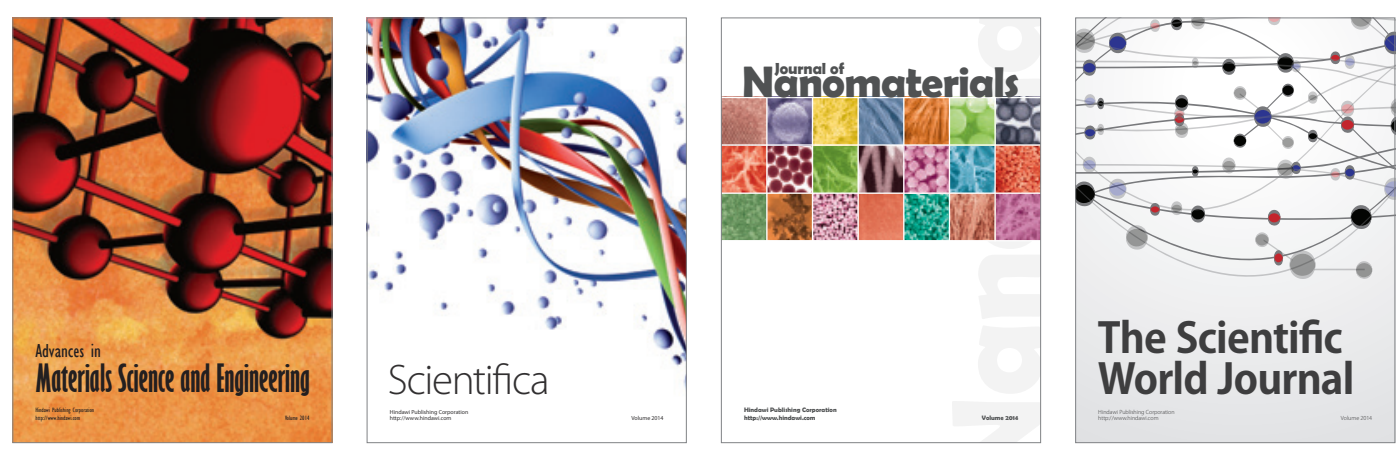

\section{The Scientific World Journal}
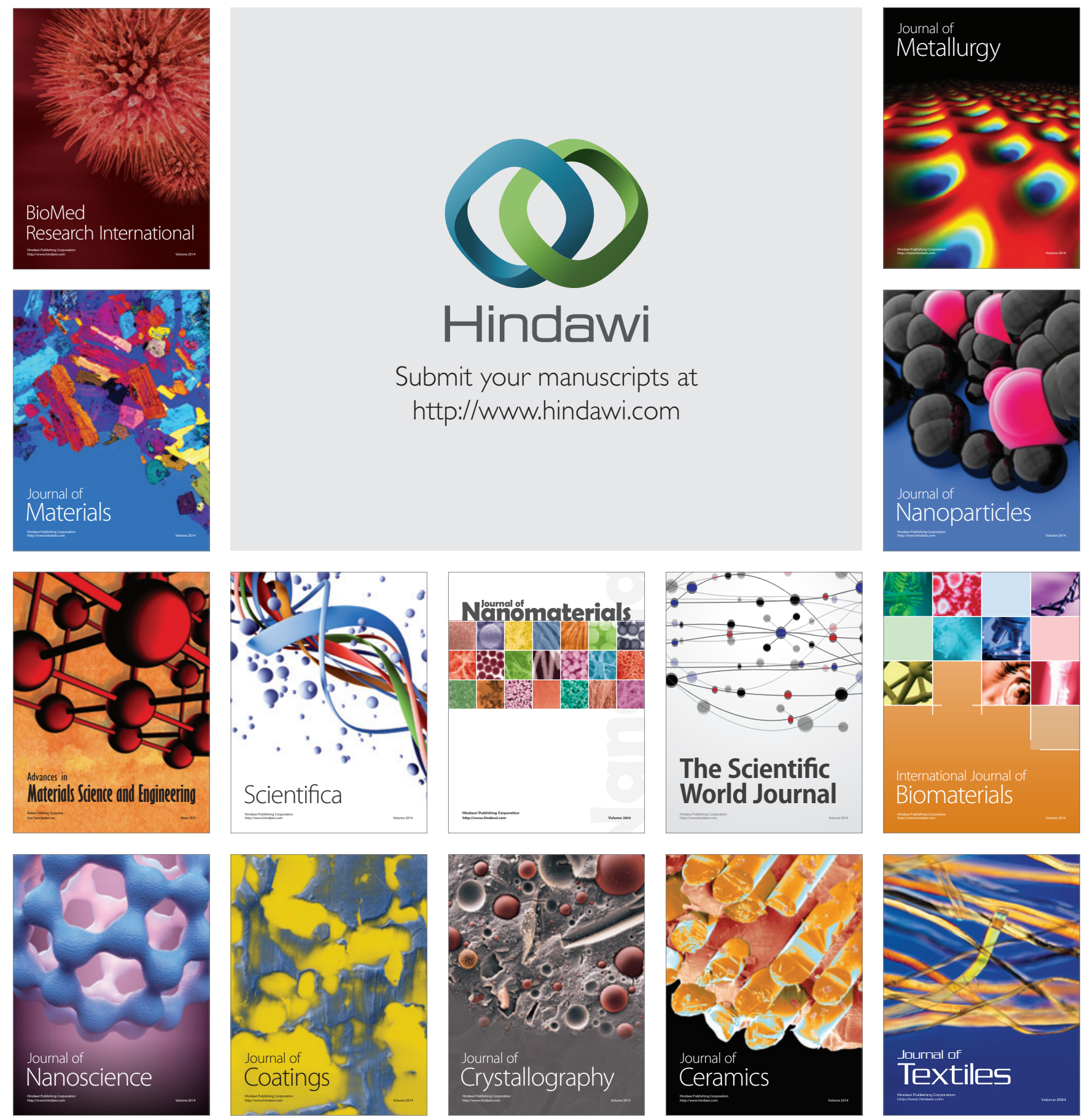